\title{
Article
}

\section{Executive pay and peformance: the moderating effect of CEO power and governance structure}

Ntim, Collins G., Lindop, Sarah, Thomas, Denise A., Abdou, Hussein and Opong, Kwaku K.

Available at http://clok.uclan.ac.uk/24755/

Ntim, Collins G., Lindop, Sarah, Thomas, Denise A., Abdou, Hussein ORCID: 0000-0001-5580-1276 and Opong, Kwaku K. (2017) Executive pay and peformance: the moderating effect of CEO power and governance structure. The International Journal of Human Resource Management, 30 (6). pp. 921963. ISSN 0958-5192

It is advisable to refer to the publisher's version if you intend to cite from the work. http://dx.doi.org/10.1080/09585192.2017.1282532

For more information about UCLan's research in this area go to http://www.uclan.ac.uk/researchgroups/ and search for <name of research Group>.

For information about Research generally at UCLan please go to http://www.uclan.ac.uk/research/

All outputs in CLoK are protected by Intellectual Property Rights law, including Copyright law. Copyright, IPR and Moral Rights for the works on this site are retained by the individual authors and/or other copyright owners. Terms and conditions for use of this material are defined in the policies page.

\section{CLoK}

Central Lancashire online Knowledge www.clok.uclan.ac.uk

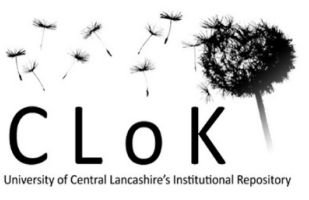


Executive pay and performance: The moderating effect of CEO power and governance structure

Collins G. Ntim ${ }^{\mathrm{a} *}$, Sarah Lindop ${ }^{\mathrm{b}}$, Dennis A. Thomas ${ }^{\mathrm{b}}$, Hussein Abdou ${ }^{\mathrm{a}}$; and Kwaku K. Opong ${ }^{\mathrm{c}}$

\author{
${ }^{a}$ Department of Accountancy and Finance \\ University of Huddersfield Business School \\ University of Huddersfield \\ Huddersfield, UK
}

${ }^{\mathrm{b}}$ School of Management and Business

Aberystwyth University

Aberystwyth, UK

${ }^{c}$ Department of Accounting and Finance

Adam Smith Business School

University of Glasgow

Glasgow, UK

*Corresponding author. E-mail: c.ntim@hud.ac.uk. Tel: +44 (0) 148447 1038. Fax: +44 (0) 1484473148. Mailing address: Financial Ethics and Governance Research Group, Department of Accountancy and Finance, University of Huddersfield Business School, University of Huddersfield, Queensgate Campus, Huddersfield, HD1 3DH, UK. 


\title{
Executive pay and performance: The moderating effect of CEO power and governance structure
}

\begin{abstract}
This paper examines the crucial question of whether chief executive officer (CEO) power and corporate governance (CG) structure can moderate the pay-for-performance sensitivity (PPS) using a large up-to-date South African dataset. Our findings are three-fold. First, when direct links between executive pay and performance are examined, we find a positive, but relatively small PPS. Second, our results show that in a context of concentrated ownership and weak board structures; the second-tier agency conflict (director monitoring power and opportunism) is stronger than the first-tier agency problem (CEO power and self-interest). Third, additional analysis suggests that CEO power and CG structure have a moderating effect on the PPS. Specifically, we find that the PPS is higher in firms with more reputable, founding and shareholding CEOs, higher ownership by directors and institutions, and independent nomination and remuneration committees, but lower in firms with larger boards, more powerful, and long-tenured CEOs. Overall, our evidence sheds new important theoretical and empirical insights on explaining the PPS with specific focus on the predictions of the optimal contracting and managerial power hypotheses. The findings are generally robust across a raft of econometric models that control for different types of endogeneities, pay, and performance proxies.
\end{abstract}

Keywords: executive pay; corporate performance; corporate governance; CEO power, endogeneity, South Africa.

JEL classification: G32, G34, G38. 


\section{Introduction}

Agency theory has recommended a number of different mechanisms, including incentive alignment (pay) and monitoring (corporate governance - CG) for addressing agency conflicts in modern companies, in which there is a separation between ownership and control (Jensen \& Meckling, 1976; Lee et al., 1995; Sanchez-Marin \& Baixauli-Soler, 2014; Ntim et al., 2015). However, while the overall aim for designing executive pay contracts is to converge the interests of managers and shareholders, such incentive contracts could themselves result in additional agency conflicts (Bonache \& Fernandez, 1997; McKnight \& Tomkins, 1999; Ding et al., 2006; Balafas \& Florackis, 2014). Not surprisingly, the pay-for-performance sensitivity (PPS) literature is underpinned by two sharply contrasting incentive alignment theories: optimal contracting theory (OCT) and managerial power hypothesis (MPH) (Murphy, 1985, 1999; Gomez-Mejia et al., 1987; Bebchuk et al., 2002; van Essen et al., 2015). The OCT posits that when properly designed, executive pay and incentive contracts can serve as powerful tools through which performance can be improved by minimising agency problems and closely aligning the interests of managers and owners (Jensen \& Murphy, 1990; Romero \& Cabrera, 2001; Cho et al., 2014); hence predicting a strong positive PPS. By contrast, the MPH suggests that managers typically have great power to determine their own pay, and that they use that power to expropriate shareholders' wealth (Bebchuk \& Fried, 2003, 2004; Bloom et al., 2003; Tien \& Chen, 2012); thus expecting the PPS to be relatively small.

The results of a good number of past papers that have investigated the association between director pay and performance suggest a positive, but relatively small PPS (Frydman \& Saks, 2010; Goergen \& Renneboog, 2011; Pepper et al., 2013), with some suggesting that performance (firm size) can explain as low (high) as less than 5\% (over 40\%) of the differences in executive pay (Tosi et al., 2000; Reddy et al., 2015). However, whilst these appear to provide support for the MPH (Bebchuk \& Weisbach, 2010; Frydman \& Jenter, 2010; Blanco \& Golik, 2015), it is quite apparent from the analyses of previous studies that a number of other reasons may also account for their evidence of relatively small PPS (Conyon, 1997; Gomez-Mejia \& Wiseman, 1997; Berrone et al., 2008; DeVaro \& Fung, 2014; Sanchez et al., 2010).

First, within the MPH, two distinct agency problems arise when setting executive pay arrangements: primary and secondary (Ding et al., 2014, 2015; Guo et al., 2015). The primary (first-tier) agency problem relates to the power that CEOs may have in setting their own pay, and in rigging the director selection process so that the independence of the board is compromised (Morse et al., 2011). The secondary (second- 
tier) agency problem concerns the apparent conflict of interests faced by directors in deciding both their own pay and that of the CEO. With compromised boards, the CEO will have extra power to influence the re-appointment, as well as the incentive contracts, of the current directors (Bebchuk \& Weisbach, 2010). This can engender a culture of mutual-favour or reciprocity, whereby an overly generous CEO pay arrangement is approved by the board in return for favourable pay packages for the directors, and thereby equally leading to excessive rent extraction. However, and whilst the first-tier agency problem has been widely investigated, the effect of the second-tier agency conflict on the PPS has seldom been investigated (Core et al., 1999, 2003).

Second, and of close relevance to our study, existing studies that have investigated the PPS by employing changes in pay and performance have also often done so by examining direct links between pay and performance without accounting for the effect of both incentive alignment (pay) and monitoring (CG) mechanisms (Main et al., 1996; Tosi et al., 2000). Further and while a limited number of past researchers have taken into account the role of CG when estimating the PPS (Chahine \& Goergen, 2011; Conyon \& He, 2011, 2012), they have mostly done so by examining direct effect of CG on the PPS without considering any potential interactions that may exist between monitoring and incentive alignment mechanisms (Lin, 2005; Chen et al., 2011). By contrast, studies assessing the extent to which CEO power and CG features may affect the PPS are rare (Cornett et al., 2009; Finkelstein et al., 2009; Li \& Srinivasan, 2011; Wowak et al., 2011). A major methodological implication is that failing to a sufficiently complex model of the PPS, that simultaneously examines the effects of both incentive alignment and monitoring mechanisms, can result in endogenous relationships (Larcker \& Rusticus, 2010; Gil-Alana et al., 2011). Existing studies, however, have mainly explored direct links between pay and performance, and thus critically failing to address potential endogeneities that may arise from the joint use of incentive alignment and monitoring mechanisms when estimating the PPS, and we argue that this may also explain the small PPS.

Finally, similar to most developing countries, South African firms face unique governance challenges in comparison with their developed counterparts. Concentrated ownership (La Porta et al., 1999), weak investor protection (La Porta et al., 2000), ineffective board structures (Dharwadkar et al., 2000; Peng et al., 2008), inactive external governance mechanisms (Young et al., 2008; Claessens \& Yurtoglu, 2013), and consequently, lower market valuation of public corporations (La Porta et al., 2002), are easily observable. In fact, past studies (e.g., Conyon \& Murphy, 2000; Firth et al., 2006, 2007) suggest that executive pay 
varies around the world because of variations in country-specific contextual factors, such as national culture, governance mechanisms, legal framework and ownership structures. This notwithstanding, previous papers have been conducted mainly in developed countries in which contextual such factors are relatively the same (Mehran, 1995; Zheng, 2010). By contrast, the PPS may arguably be different in less developed and emerging economies where there are considerable differences in the contextual factors, such as those articulated above. Therefore, examining the PPS in less developed and emerging economies, in which there is scarcity of studies may provide new insights on this relationship.

Consequently, the current research aims to offer both extensions to, and new insights on, existing studies by resolving weaknesses inherent in them. First, we investigate the extent to which the PPS can be moderated by CEO power and CG qualities over a ten-year period. This finding makes a contribution to existing research by demonstrating that the PPS differs depending on CEO power and CG structures. Second, given the separate agency conflicts that can arise from incentive contracts, we distinctively and explicitly examine both the effects of the primary (CEO pay) and secondary (all executive directors' pay) agency problems on the PPS. Our findings contribute to the literature by indicating that in a context of concentrated ownership and weak board structures; the second-tier (monitoring power and opportunism of other directors) agency conflict is stronger than the first-tier (CEO power and opportunism) agency problem. Finally, the current findings make a contribution to existing studies by showing that the PPS for both the CEO and all executive directors is generally small, but relatively strong in better-governed firms.

The rest of the paper is structured as follows. The following sections review existing research, outline the research design, report the empirical analyses, and provide a conclusion.

\section{Theory, prior empirical literature and hypotheses development}

In modern corporations, ownership tends to be diverse, whereas the firm is controlled and managed by a small set of professional executives (Berrone et al., 2008; Ntim et al., 2015). This generates a classic agency conflict, where opportunistic managers are assumed to have a higher tendency to operate against the interests of shareholders. Different mechanisms, including incentive alignment (pay) and monitoring (CG) have, therefore, been suggested to motivate managers to pursue an objective of maximising values for shareholders (Jensen \& Meckling, 1976). A major way of aligning the interests of owners and managers is to design appropriate pay incentives (Morse et al., 2011; Pepper et al., 2013), and this is the main idea 
underlying a number of executive pay and governance reforms that have been embarked upon worldwide (Cadbury, 1992; King, 2002). Discernibly, the crucial question, as to whether such executive pay incentives are effective in improving performance has equally generated a considerable theoretical and empirical literature (See Murphy, 1999; Gomez-Mejia \& Wiseman, 1997; Tosi et al., 2000; Core et al., 2003; Finkelstein et al., 2009; Frydman \& Jenter, 2010; Chen et al., 2011; van Essen et al., 2015 for insightful reviews).

Theoretically, there are two major contrasting views: OCT and MPH (Murphy, 1985; Bebchuk \& Fried, 2003). On the one hand, the OCT views executive pay contracts as free market product arising from independent negotiations between strong corporate boards and executives, leading to executive pay packages that efficiently bring together the interests of managers and owners (Jensen \& Murphy, 1990; He et al., 2014). As a result, the OCT expects a tight link between pay and performance (PPS) (Dong et al., 2010; Upneja \& Ozdemir, 2014).

On the other hand, the MPH suggests that executive pay packages often results from negotiations between dependent boards and influential managers, leading to the creation of managerial incentive deals that rather encourages divergence of managerial interests from those of shareholders instead of converging them (Bebchuk et al., 2002; Sapp, 2008). Meanwhile, it should be noted that excessive managerial power can create two distinct agency conflicts. A first-tier agency conflict relates to the ability of the CEO to manipulate director appointment in order to gain control over board decisions that can facilitate excessive rent extraction (Gomez-Mejia eta al., 1987). A second-tier agency problem arises because directors may reward a CEO with an excessively high pay in return for a similar and reciprocal support from the CEO (Core et al., 2003; Morse et al., 2011). Due to the assumption that powerful managers determine their own pay (Bebchuk \& Fried, 2003, 2004), the MPH expects a small, but not necessarily negative PPS, as it is possible for managers to be paid for 'luck' (i.e., for improved performance outside executive control, such as general improvement in the broader macro-economic and political environment) (Bertrand \& Mullainathan, 2001).

Past studies relating to the PPS have two observable characteristics: (i) their findings are generally mixed; and (ii) they have been conducted mainly in developed countries, especially in British and American firms (Gomez-Mejia eta al., 1987; Hubbard \& Palia, 1995; Main et al., 1996; Zheng, 2010; Balafas \& Florackis, 2014; Kale et al., 2014; Kuo et al., 2014). The findings of most of the existing papers 
indicate that the PPS is comparatively small, albeit the relationship is reported to be tighter among American firms compared with their British counterparts (Conyon \& Murphy, 2000; Tosi et al., 2000). For example, using a sample of 1,049 American firms between 1974 and 1976, the findings of Jensen and Murphy (1990) suggested that the PPS is positive. Also, using a sample of 60 British firms over the 19811989 period, Main et al. (1996) found a similar positive PSS, but was smaller in comparison those reported by American researchers. Whilst this appears to provide support for the MPH, pioneering British and American research has observable weaknesses - a limited number of control measures, and in particular, governance variables, which can possibly influence both the direction and magnitude of the resulting PPS.

In order to address the problem of limited control variables, especially governance ones, British (Benito \& Conyon, 1999; Dong \& Ozkan, 2008; Balafas \& Florackis, 2014) and American (Mehran, 1995; Core et al., 1999; Dong, 2014; Upneja \& Ozdemir, 2014) researchers that followed the pioneering researchers included a large number of control variables, especially governance variables in estimating the PPS, but have still provided evidence that suggests that the PPS is essentially small. However, the main problem with these studies is that they fail to account for possible endogeneities that can emerge from the joint application of both managerial incentives (pay) and monitoring (CG) mechanisms by corporations in resolving the agency conflict. These studies have also mostly examined the PPS for CEOs rather than other executive directors. Thus and arguably, the observably small PPS found by previous researchers may be accounted for by these limitations (Dong, 2014; van Essen et al., 2015).

Noticeably, small, but gradually increasing number of non-British and American researchers have found evidence of positive PPS (Cho et al., 2014; Ding et al., 2015). Discernibly, the PPS reported by nonBritish and American researchers are, on average, higher than those reported by British and American researchers, and therefore, suggests that the PPS is seemed to be determined by both firm-level features and country-specific contextual factors. In particular, contextual differences in the effectiveness of board and ownership structures, legal, regulatory and enforcement environment, and markets (e.g., capital, control, labour, product and services) can explain the differences in the level of PPS that is observed across different countries (Li \& Srinivasan, 2011; Wowak et al., 2011; Sanchez et al., 2010; Sanchez-Marin \& Baixauli-Soler, 2014). In the Britain and America, for example, ownership is often widely held within a fairly strong internal governance structures, and cultural, legal, regulatory and enforcement environment. This renders the external (governance) market for capital, corporate control, and labour highly active, and 
thereby serving as additional effective check on managerial capacity to expropriate corporate resources through excessive pay.

By contrast, in most developing countries, such as South Africa, ownership is usually held by a few block holders who usually dominate decisions (e.g., board appointments), and thereby weakening the ability of the board to effectively monitor managers. Concentrated ownership also renders external governance mechanisms, such as corporate control inactive, and thereby placing minority shareholders' interest at risk of expropriation by majority shareholders. In fact, and as an example of the case of research context potentially accounting for differences in the level of PPS that is observed, Sapp (2008 found positive and larger PPS for 416 Canadian firms from 2000 to 2005 in comparison with those found by American and British researchers. Similarly, larger positive PPS has been reported by Kaplan (1994), Kang and Shivdasani (1995), Angel and Fumas (1997), Cheng and Firth (2005) and Merhebi et al. (2006), employing German, Japanese, Spanish, Hong Kong and Australia companies, respectively, compared with those reported by American and British researchers.

In addition, and of immediate importance to this study is that the findings of studies that have been conducted in less developed and emerging economies are qualitatively similar to those found by nonAmerican and British researchers of findings a positive and larger PPS. For example, Conyon and He (2012) found positive and larger PPS for a sample of 2,104 Chinese firms from 2000 to 2010 compared to those found by American and British researchers. Indeed, the findings of research conducted in China by Firth et al. (2006, 2007), Kato et al. (2006), Buck et al. (2008), Conyon and He (2011) and Ding et al. (2015), along with those executed by Jones and Kato (1996), Kumar and Kaura (2002), and Cho et al. (2014) in Bulgaria, India, and Taiwan, respectively, are largely in line with those reported by nonAmerican and British researchers. Therefore, given that the international evidence is broadly consistent with the predictions of the MPH, our first hypothesis is that:

\section{Hla: The PPS is positive.}

As previously explained and within the MPH, two distinct agency problems arise when setting executive pay arrangements: primary and secondary (Bebchuk et al., 2002). A first-tier agency conflict relates to the ability of the CEO to manipulate director appointment in order to gain control over board decisions that can facilitate excessive rent extraction (Gomez-Mejia eta al., 1987). A second-tier agency problem arises because directors may reward a CEO with an excessively high pay in return for a similar 
and reciprocal support from the CEO (Morse et al., 2011). Whilst the first-tier agency problem has been widely acknowledged and investigated (Frydman \& Jenter, 2010), the effect of the second-tier agency conflict on the PPS has seldom been investigated (Core et al., 2003). Thus, and given the separate agency conflicts that can arise from incentive contracts, we distinctively and explicitly examine both the effects of the primary (CEO pay) and secondary (all executive directors' pay) agency problems on the PPS. We expect that in firms with powerful CEOs and weak monitoring (board and ownership structures) mechanisms, incentive contracts will be generously favourable to their CEOs, and therefore a weak PPS, as predicted by the MPH. However, in firms with strong governance, we expect that greater and closer managerial monitoring will help improve the PPS even in the face of suboptimal CEO incentive contracts, as predicted by OCT. We make similar predictions for the pay of all executive directors, but given the strategic and influential role of the CEO, the PPS for the CEO is expected to be larger than that of all executive directors.

We seek to test this proposition in South Africa where recent CG and executive pay reforms that have been pursued arguably render it interesting context to do so. Indeed, the publication of the first King Report on CG for South Africa (King I) in 1994 was an important part of a number of efforts directed at enhancing CG standards in South Africa firms (Armstrong et al., 2006). Specifically, the first King Report placed crucial emphasis on the need to have effective boards of directors (Ntim et al., 2012a, b). With specific regard to directors' pay, the first King Report recommended that the remuneration committee is responsible for its design, implementation and administration (see Table 1). The first King Report, however, did not clearly specify how the remuneration committee need to be composed of in order to enhance its independence, and crucially, the form, extent and medium of disclosing information relating to director pay (see Table 1; Ntim et al., 2015). Further and although the first King Report recognised the importance of board sub-committees, it failed to recommend the establishment of a nomination committee (see Table 1) that would have nominated new independent directors for appointment to corporate boards (Ntim et al., 2013). Arguably, this weakened the power of the remuneration committee, and the board to effectively monitor executive incentive contracts under the first King Report.

Insert Table 1 about here

South Africa witnessed a number of bankruptcies of number of companies in the 1990s, such as the Nedbank Corporation (Sarra, 2004). These corporate failures were generally believed to have been caused 
at least partly by governance weaknesses in South African companies. Meanwhile there were major global corporate failures, especially in Britain and America, which were believed to have also at least partly been caused by ineffective governance practices in companies. Consequently, the first King Report was reviewed and replaced with a second King Report on CG in South Africa in 2002 with the aim of further improving governance practices in South African firms. In general, the second King Report sought to further develop and extend good governance practices that were recommended by the first King Report. Observably, and unlike the first King Report, a separate section (Section 2.5) devoted to addressing executive pay issues was contained in the second King Report.

First and most noticeably, the second King Report suggests that the remuneration committee should be composed entirely by independent directors (see Table 1; Armstrong et al., 2006). Second, to improve the independence of the director selection process, the second King Report explicitly suggested the establishment of an independent nomination committee. In terms of membership, the second King Report suggested that the committee should be chaired by (i) an independent director and (ii) more than $50 \%$ of its membership should be independent directors. Third, and unlike the first King Report, the second King Report explicitly specifies how executive pay should generally be structured, consisting of a fair mix of cash and equity-based incentives that is competitive in order to recruit, reward and hold on to managers with the right level of skill and competence, who will be capable of delivering excellent performance for the company (see Table 1). Additionally, it suggests that corporate boards should consider the suggestions and opinions of CEOs, when deciding on the pay packages of other executive directors, but that a CEO should not play any direct part in decisions relating to her/his own pay.

Fourth, in addition to the remuneration committee and board, the second King Report sets an expectation that owners of shares in corporations, especially large share owners will take active part in deciding the pay of executives. An important improvement on the first King Report is the requirement that director pay be voted on by all share owners at an annual general meeting, whereby the chair of the remuneration committee is expected not only to consult the views of the major institutional shareholders when setting director pay, but to also attend annual general meeting in order to answer any pertinent questions that share owners may have (see Table 1). In effect, the second King Report presumes that encouraging greater shareholder activism (i.e., having "say-on-pay"), including potential outrage from institutional owners and the general public, can help in restraining executive pay. 
Fifth, and different from the first King Report, the second King Report explicitly indicates the exact items, frequency and medium of disclosing information relating to director pay (see Table 1; Malherbe \& Segal, 2003). Specifically, the second King Report required corporations to fully disclose individual managers, non-executive and independent director's remuneration packages, providing the breakdown in terms of salaries, fees, pension contributions, bonuses, restraint payments, share options and all other benefits in the annual report. Overall, and in comparison with the first King Report, the second King Report is comprehensive in terms of focus and scope, and strengthens the independence and monitoring power of the remuneration committee, board and shareholders. However, it should also be noted that some of the proposals, such as the suggestion for the remuneration committee to seek the views of the CEO when setting the pay packages of other executive directors, could themselves potentially give rise to extra agency conflicts (second-tier agency conflict).

Apart from the governance and executive pay reforms that have been pursued in South Africa as articulated above, and distinct from British and American companies, the share ownership structure of companies is significantly concentrated, often through complicated pyramidical share ownership mechanisms (La Porta et al., 1999; Malherbe \& Segal, 2003). In addition, implementation, compliance and enforcement of corporate regulations in South Africa has traditionally been weak. These contextual factors render the corporate control market inactive, and thereby exacerbating agency conflicts, such as managerial expropriation of shareholder wealth through overly generous pay packages (Sarra, 2004). In this setting, it is arguable to expect that the first-tier agency problem to be weaker than the second-tier agency problem in the form of smaller PPS relating to the executive directors compared with that of CEOs, and therefore, our next hypothesis is that.

H1b: The second-tier agency conflict is expected to be stronger than the first-tier agency problem.

\section{The moderating effect of CEO Power and CG structure on the PPS}

As previously explained, although a limited number of studies have examined the direct effect of CG on the PPS (Core et al., 1999; Cornett et al., 2009; Sanchez et al., 2010; Conyon \& He, 2011, 2012; Reddy et al., 2015; van Essen et al., 2015), studies examining the moderating (joint) effect of CG and especially CEO power on the PPS even within a developed corporate setting are rare (Li \& Srinivasan, 2011; Wowak et al., 2011). Thus, this section seeks to make a number of new contributions to the extant literature by 
briefly ascertaining whether governance mechanisms and CEO power moderate the PPS within a developing corporate context.

\section{The effect of CEO Power on the PPS}

Prior studies have identified a number of CEO power attributes, including CEO age, duality, founding status, ownership, power, reputation and tenure, which can have important implications for CG, performance and the PPS (Conyon, 1997; Lippert and Porter, 1997; Benito \& Conyon 1999; Lin, 2005; Sapp, 2008). We, therefore, focus on the effect of these seven (CEO age, duality, founding status, ownership, power, reputation and tenure) CEO power attributes on the PPS in the current study. From an MPH perspective, powerful CEOs, as represented by role duality and long-tenure, for example, may have greater control over the board and the pay-setting process, which can impact negatively on the PPS (Cornett et al., 2009). Theoretically, CEO role duality is considered detrimental because it vests more power and control in the CEO, which can generate extra agency problems, including granting CEOs greater freedom to engage in suboptimal pay practices (Conyon \& He, 2011, 2012). In contrast, separating the two roles can improve monitoring by reducing the concentration of power in CEOs, which can facilitate an objective assessment of a CEO's performance (Conyon, 1997), and thereby improving the PPS.

With respect to CEO reputation, Sanchez-Marin and Baixauli-Soler (2014) suggest that one of the results of increased public recognition and reputation (e.g., positions in peer rankings and wining of awards/prizes) of CEOs is that it facilitates non-performance induced increases in their pay packages, which can impact negatively on the PPS. Moreover, long-tenured and older CEOs are perceived to have greater experience and skill that can guarantee firm competitiveness and success (Sanchez et al., 2010), and are therefore, often offered higher pay packages that are not necessarily linked to their performance than their younger and less experienced colleagues, which can also impact negatively on the PPS. By contrast, increased commitment (OCT view) that is often displayed by founding, reputable and high shareholding CEOs can have a positive effect on the PPS (Wowak et al., 2011). Further, founding and shareholding CEOs, for instance, often offer a number of advantages, including possessing expert, in-depth and firmspecific knowledge about corporate strategy and operations that reduces information asymmetry between boards and managers, holding concentrated and long-term ownership, and having large non-financial attachments and social interests to protect (e.g., emotional, psychological and reputational capital). Thus, 
the greater pecuniary and non-pecuniary interests that founding CEOs often have in their corporations can provide them with greater incentive and ability to engage in closer monitoring of managers, and thereby leading to improved PPS.

The empirical literature is broadly consistent with the view that ensuring a balanced distribution of power at the top reduces the influence that CEOs may have over the pay setting processes and institutions, which can impact positively on the PPS (Lippert \& Porter, 1997; Benito \& Conyon 1999). For example, using 865 US listed firms from 2000 to 2005, Chhaochharia and Grinstein (2009) report that the level of CEO pay is greater in companies with CEO role duality than their counterparts with separate chairman and CEO positions. Conyon (1997), Core et al. (1999), Lin (2005) and Sapp (2008), for samples of British, Taiwanese and Canadian listed companies, respectively, have reported similar findings. With reference to founding status, Li and Srinivasan (2011) report a higher PPS for firms with serving founder CEOs than those that are not. Similarly, Sanchez-Marin and Baixauli-Soler (2013) report higher PPS for firms with CEOs with high reputation for performance than those that are not. In contrast, other studies report a lower PPS for firms with more powerful (e.g., having higher peer rankings), older and long-tenured CEOs (Bertrand \& Mullainathan, 2001; Cornett et al., 2009; Wowak et al., 2011). With respect to South Africa, the second King Report states explicitly that there should checks and balances such that too much power is not concentrated in one person, including the recommendation that the posts of chairman and CEO should not be held by the same individual in order to permit a clear division of responsibilities at the head of the company. This suggests that the second King Report recognises balance of power within top management as a good CG practice and, therefore our second hypothesis is that:

H2: CEO power has a moderating effect on the PPS.

\section{The effect of ownership structure on the PPS}

An important CG mechanism that can moderate the PPS is ownership structure of the firm (van Essen et al., 2015). The extent to which the board is able to effectively monitor executives will depend on the level of ownership concentration/distribution (e.g., block, director and institutional shareholdings) and the type of influence that may be exerted by these owners, especially major shareholders (Wowak et al., 2011; Sanchez-Marin \& Baixauli-Soler, 2014). Consequently and in this study, we examine the extent to which these three ownership structures (block, director and institutional shareholdings) can have a moderating 
effect on the PPS. For example, greater monitoring that is often associated with concentrated shareholding structure can act as an effective alternative incentive alignment mechanism that is able to effectively restrain executive pay and improve the PPS (Cheng \& Firth, 2005; Ding et al., 2015), although concentrated ownership can also have costs implications for minority shareholders, including entrenchment and extraction of private benefits. Block shareholders can, for instance, connive with executives to engage in fraudulent activities, such as 'tunnelling', or expropriate firm assets in the form of high pay at the expense of minority shareholders (Conyon \& He, 2011, 2012), which can impact negatively on the PPS. This is more likely to be a problem in South Africa where corporate share ownership has traditionally been held by a small number of of very large firms often with the shares held in complex structures and pyramids (Ntim et al., 2012a, b). Similarly and due to their larger shareholdings, institutional share owners can apply greater pressure on managers to act in their best interests on a number of issues such as, deciding the appropriate executive pay (Sapp, 2008). Institutional shareholders also enjoy knowledge and information advantages over individual or less-informed investors, which can facilitate greater activism and managerial monitoring that can impact positively on the PPS (Hartzell and Starks, 2003; Ding et al., 2015). Also, the alignment of interest that is often associated with director ownership can have a positive effect on the PPS (Morck et al., 1988; Li \& Srinivasan, 2011).

Empirically, the evidence is largely in line with the prediction that the presence of a large shareholder enhances managerial monitoring, reduces executive pay and improves the PPS (Kang \& Shivdasani, 1995; Lin, 2005; Mehran, 1995; Ozkan, 2011). For example, Core et al. (1999) report that block ownership reduces the likelihood of CEO entrenchment, which impacts positively on the PPS for a sample of 205 American companies. In a similar vein, Bertrand and Mullainathan (2001), Sapp (2008), and Conyon and He (2011), respectively, found that American, Canadian and Chinese companies with high levels of ownership concentration reward their CEOs less in comparison with their counterparts with dispersed share ownership structure.

With respect to institutional ownership, Hartzell and Starks (2003), Sapp (2008), and Ozkan (2011), respectively, found that American, Canadian and British firms with high levels of ownership institutions reward their CEOs less in comparison with their counterparts with less levels of share ownership by institutions. In contrast, the findings of Zheng (2010) report that shareholdings by institutions has no effect on CEO pay using a sample of American companies. However, and as previously discussed, 
the second King Report encourages institutional share owners to get involve in determining executive pay in South African companies, including being directly consulted for their views. A major implication of this is that institutional shareholders in South Africa can exert their influence on executive pay not only through voting, but also with a direct voice (i.e., have "say-on-pay") on the remuneration committee/board. Further, Li and Srinivasan (2011) and Sanchez-Marin and Baixauli-Soler (2013) report that director ownership impacts positively on the PPS. Thus, and given the inherent pervasiveness of block, institutional and director shareholdings in South Africa (Ntim et al., 2012a, b; 2015), our third hypothesis is that:

H3: Ownership structure has a moderating effect on the PPS.

\section{The effect of board structure (effectiveness) on the PPS}

Boards of directors play crucial roles in modern public corporations. These may include monitoring, disciplining and compensating corporate executives in order to ensure that they operate in the best interest of share ownership (Beiner et al., 2006; Finkelstein et al., 2009), but their effectiveness is usually influenced by the way they are structured (e.g., size, composition, committees and meetings) (Cornett et al., 2009; Sanchez et al., 2010). Hence and in this study, we assess the moderating effect of these five board structures (board size, board meetings, proportion of NEDs, independent remuneration committee, and independent nomination committee) on the PPS. For instance, increased coordination and communication challenges often related to having larger boards can impair their monitoring efficacy, and this may be manifested in the form of excessive managerial pay (Core et al., 1999; Ozkan, 2011). By contrast, as boards become smaller, their ability to hold frank discussions and engage in more effective managerial monitoring improves and, therefore, smaller boards can be expected to enhance the PPS. Similarly, non-executive directors (NEDs) have more incentives to effectively monitor CEO pay, not only because they are less subject to CEO influence, but also have reputations to protect in the labour market (Core et al., 1999; Conyon and He, 2011).

Others suggest that executive pay decisions should be delegated to independent $N E D s$ because they are better able to make unbiased judgments about the performance of the CEO and, in turn, decisions regarding firing, hiring and pay (Ozkan, 2011). Also, Cornett et al. (2009) suggest that increased managerial monitoring associated with regular board meetings can impact positively on the PPS. Further, in most listed firms, the independent remuneration and nomination committees are the primary mechanism for 
monitoring and setting executive pay (Conyon, 1997; Bebchuk et al., 2002). Thus, their absence can exacerbate agency conflicts by giving CEOs more power to award themselves pay rises, which are not congruent with shareholders' interests (Benito and Conyon, 1999; DeVaro \& Fung, 2014). Thus, and in theory, establishing these committees can improve the PPS by reducing the influence that CEOs have in setting their own pay. However, and to the extent that powerful CEOs can handpick members of the board and remuneration committee, their monitoring effectiveness will depend on the independence of the remuneration committee's members from the CEO (Chhaochharia \& Grinstein, 2009). As director independence depends heavily on the nominating authority (Vefeas, 1999), in companies that do not have independent nomination committee, whereby director selection is dominated by their CEOs, the effectiveness of the remuneration committee in setting optimal CEO pay may be seriously undermined (Bebchuk \& Fried, 2003; Conyon \& He, 2011, 2012). Therefore, the presence of an independent remuneration committee largely depends on the presence of an independent nomination committee, and consequently, the ability of the remuneration committee to effectively monitor CEO pay.

The empirical evidence largely suggests that effective board structures can have positive effect on the PPS (Cornett et al., 2009; Li \& Srinivasan, 2011; Wowak et al., 2011; Sanchez et al., 2010). For example, Core et al. (1999), Sapp (2008), Ozkan (2011), and Conyon and He (2011), respectively, found that larger American, British, Canadian and Chinese boards pay their CEOs higher than their smaller counterparts, and thus larger boards tend to have a negative effect on the PPS. The empirical evidence relating to NEDs is, however, mixed. Core et al. (1999), Li and Srinivasan (2011), Ozkan (2011), and Conyon and He (2011), respectively, report that American, British and Chinese firms with more NEDs paid their CEOs more than those with smaller NEDs; leading to a lower PPS, while the findings of Cheng and Firth (2005), Lin (2005), and Chhaochharia and Grinstein (2009) suggest that Hong Kong, Taiwanese and American firms with higher proportion of independent directors pay their CEOs less compared with their counterparts with lower proportion of outside directors; and thereby resulting in a higher PPS, respectively. Other studies (Mehran, 1995; Fernandes, 2008; Sapp, 2008) report that the presence of NEDs has no impact on CEO pay and the PPS. Also, Cornett et al. (2009) report that the number of board meetings has a positive effect on the PSS. Finally, the empirical evidence is generally consistent with these theoretical predictions relating to the effect of nomination and remuneration committees on the PPS (Benito \& Conyon 1999; Sun \& Cahan, 2009). For example, and consistent with Vefeas (1999), Chhaochharia and Grinstein 
(2009) document that American firms that have established a nomination committee tended to, on average, appoint new directors with the ability to engage in high quality monitoring executives and contribute to quality board decision-making. Similarly, Conyon (1997), Sapp (2008) and Conyon and He (2011, 2012) find that the level of CEO pay is significantly lower and the PPS significantly higher in companies with independent remuneration committees.

In the South African case, the second King Report recommends that corporate boards should consist of majority independent outside directors, suggesting that increasing the number of NEDs is viewed as a positive CG development. The second King Report, however, fails to indicate to companies how many directors should their boards consist of. It instead outlines an overriding principle that every corporate board needs to ascertain whether it has the appropriate mix directors in terms of skills, experience, demography, gender and ethnicity in order to make its work effective, and thereby suggesting that board size is viewed to be a vital governance structure by the second King Report. Further, the second King Report requires that the remuneration committee and nomination committee to be established, consisting of independent $N E D s$, and including the chairpersons. This suggests that the second King Report considers the two committees as good governance mechanisms. Moreover, the second King Report suggests that regular board meetings is a mark of conscientious board, and as such recommends that boards should meet as frequently as possible, at least four times in a year. Put together, it can be argued that the second King Report expects these board structures (board size, meetings, independent NEDs, nomination committee and remuneration committee) to impact on the PPS, and therefore our final hypothesis is that:

\section{H4: Board structure has a moderating effect on the PSS.}

\section{Research design}

\section{Data considerations}

As summarised in Table 2, due to capital structure and regulatory reasons, we excluded 111 financials and utilities from the total sample of 407, and thus we draw the sample from all 291 non-financial companies quoted on the South African stock exchange as at 31/12/2012. The data employed was collected from two different sources. In the first place, data relating to the pay of executives and governance structures was collected from annual reports of the sampled companies. The annual reports were collected from the Perfect Information Database. Distinct from past researchers that have collected data only on 
CEO pay (Jensen \& Murphy, 1990; Kale et al., 2014), the pay data relating both CEOs and lower placed executive directors was extracted from the annual reports. This permitted us to explicitly test both the primary and secondary agency problems. Second, accounting, stock market and financial data was collected from DataStream. We set two main criteria for companies included in our final sample. First, the company's annual report from 2003 to 2012 (for pay and governance data) and accounting, financial and stock data from 2002 to 2011 needed to be available in Perfect Information Database and DataStream respectively. This data collection structure permitted us to estimate ex-ante PPS. We imposed these sample selection criteria for the following reasons. In the first place, the pay and CG data was manually collected, which was very labour intensive and therefore, we restricted the final sample to companies which had continuous years data available. In the second place, and in line with the suggestions of past research (Core et al., 1999; Jimenez-Angueira \& Stuart, 2015), this criteria helped us to meet the conditions of balanced panel data analysis with its well documented advantages. Third, as suggested by Wowak et al. (2011), investigation of a 10-year data, which possesses both time-series and cross-sectional characteristics can be helpful in determining as to whether the cross-sectional relationship between pay and performance that has been determined also holds over-time. As a final criterion, the sample starts in 2002 due to lack of data in the Perfect Information Database/DataStream on South African firms before this year, and importantly due to the fact that the second King Report was implemented in this particular year. The data collection began in 2012, and therefore the data collection ends in that year as the year when the most recent data was available on the firms in our final sample. As contained in Table 2 (after excluding 122 firms with no or some years data missing), the final sample made up of a total of 169 companies over 10 firm-years (i.e., 1,690 observations) from 8 industrial sectors that satisfied our sample selection criteria for the empirical analysis.

Insert Table 2 about here

\section{Variables: Pay, performance, CEO/CG characteristics, interaction and control variables}

We classify our variables into seven main types and full definitions of all the variables used are presented in Table 3. First, and following a well-established line of research (Murphy, 1985; Jensen \& Murphy, 1990; Conyon \& He, 2011), total pay of all executives (TEPAY) and the CEO (CEPAY) are our main dependent variables. Second, our main performance proxy is the widely used total return for 
shareholders $(T R S)$, but as a robustness check, we also employ operating return on assets $(O R O A)$ and Tobin's $\mathrm{Q}(Q)$ as alternative accounting and market-based performance measures, respectively. The third group consists of CEO power proxies, including CEO age (CEOA), CEO duality (CEOD), CEO ownership $(C E O O)$, CEO power $(C E O P)$, CEO reputation $(C E O R)$, CEO tenure $(C E O T)$ and founding CEO $(F C E O)$. The fourth group consists of board structure variables, including board size (BSIZ), percentage of independent non-executive directors (INEDs), frequency of board meetings $(F B M)$ and the presence of independent remuneration $(R C O)$ and nomination $(N C O)$ committees, whilst the fifth group is made up ownership structure variables, including block ownership $(B O W)$, director ownership $(D O W)$ and institutional ownership $(I O W)$. Sixth, and to test for the moderating effect of CEO power/CG features on the PPS, we create an interaction variable between each of our monitoring CEO power/CG structure and performance (e.g., $P^{*} C E O A, P^{*} B O W$, and $P^{*} B S I Z$ ). Finally, and to attenuate potential omitted variables bias (Petersen, 2009), we include an extensive number of control variables (see Table 3).

Insert Table 3 about here

\section{Empirical analyses and discussion}

\section{Descriptive statistics}

Table 4 presents summary descriptive statistics in terms of executive pay, performance, CEO, CG and control variables, and are reported in Groups A, B, C, D and E, respectively. The table suggests wide variation in the distribution of TEPAY and CEPAY values. CEPAY, for example, has a minimum value of R0.06 million and a maximum of value of R16.86 million with a mean of R2.89 million. Observably, and in spite of the second King Report's recommendation that equity-based pay should form the substantial portion of executives' pay with the aim of closely converging the interests of shareholders and executives, cash pay remains a bigger part of total executive pay in South African corporations. For example, the mean total equity-based pay of all executives (TEPAY EQUITY) of R1.66 million is only about $13 \%$ of the mean total pay (TEPAY) of R12.92 million.

Insert Table 4 about here

Similarly the values of the performance, CEO, CG and control variables, overall suggests that there are wide variations in our sample. For instance, and similar to the results of Mehran (1995), TRS spans between $-48 \%$ and $236 \%$ with a mean of $28 \%$, suggesting that a clear majority of companies included in our final 
sample reported a profit. The median $C E O A$ is 53, ranging from 34 to 81 years, whilst the average $C E O T$ is 7, ranging from 3 months to 42 years. About $19 \%$ of our CEOs are founders, whilst about $23 \%$ doubles-up as CEOs and chairpersons. The average CEO is powerful $(C E O P)$, with his/her pay accounting for $48 \%$ of all the other executives put together. These findings are roughly comparable with those reported by Cornett et al. (2009), Li and Srinivasan (2011) and Wowak et al. (2011) for American CEOs. The median BSIZ of 10 is smaller compared with the 13 that Core et al. (1999) reported for a sample of American companies, whilst the mean of $57 \%$ INEDs is similar to the $62 \%$ that Lee et al. (2008) reported for a sample of American firms. The average IOW of $74 \%$ is similar to the $63 \%$ that Zheng (2010) reported for a sample of American companies, whilst the mean $B O W$ of $62 \%$ is significantly larger compared with the $20 \%$ that Ozkan (2011) reported for a sample of British companies. Observably, only $14 \%$ of our sampled companies have established a RCO, which is significantly less compared with the 66\% that Brown and Caylor (2009) reported for a sample of American firms.

Insert Table 5 about here

Table 5 presents the correlation matrix for the variables with the view to testing for the presence of any multicollinearities. However, as a sensitivity check, we present both the Pearson's parametric and Spearman's non-parametric coefficients and, observably, the magnitude and direction of both coefficients are essentially the same and thus, indicating that any residual abnormal distribution behaviour in the dataset may not statistically harmful. Noticeably, apart from the predicted high correlation between $T E P A Y$ and $C E P A Y$, the bivariate correlations among all the other variables are largely small and thus, suggesting that any remaining multicollinearities may not be statistically harmful. Observably, the TRS, CEOP, CEOR, $C E O T, F C E O, B O W$ and $B S I Z$ are positively associated with TEPAY, whilst DOW, IOW, NCO, INEDs and $R C O$ are negatively related to $T E P A Y$. Additionally, there exist significant associations among the $T E P A Y$, CEPAY, TRS, CEO, CG and the control variables used.

\section{Multivariate regression analyses}

\section{Estimating the PPS}

We conduct multiple regression analyses in order to empirically test our hypotheses. Fixed-effects regressions have the benefit of incorporating undiscernible company-specific heterogeneities, such as corporate culture, firm complexity, and managerial quality (Conyon \& He, 2011). Following prior research 
(Wowak et al., 2011; Li \& Srinivasan, 2011), we adopt a lagged structure with median (in order to account for the observable large pay differentials) fixed-effects to estimate ex-ante PPS using Jensen and Murphy (1990) style first difference approach. Consequently, we begin the empirical regressions with a simple fixed-effects model defined in this form:

$$
\operatorname{TEPAY}_{i t}=\alpha_{0}+\beta_{1} \operatorname{TRS}_{i t-1}+\sum_{i=1}^{10} \beta_{i} \text { CONTROLS }_{i t-1}+\delta_{i t-1}+\varepsilon_{i t-1}
$$

where: TEPAY refer to the key dependent variable; TRS is the main independent variable; CONTROLS is the control variables included and $\delta$ refers to the company-specific fixed-effects, made up of a vector of the mean-differences of all time variant variables.

Table 6 contains a fixed-effects regression of the PPS, with results reported for three models for both all executive directors' pay and CEO pay consisting of cash, non-cash and total as the dependent variables. First, the main aim of designing managerial incentives contracts is to align the interests of owners and managers. However, such contracts, could themselves, create primary agency problems, whereby powerful CEOs may use their influence to expropriate corporate resources. To investigate this first-tier agency conflict that exists between CEOs and shareholders, we examine the sensitivity of TRS to CEPAY. The coefficient of TRS on CEPAY in Model VI of Table 6 is statistically significant and positive. However, and consistent with prior studies the PPS is relatively small at 0.095 , and thereby provides support for $H 1 a$ that the PPS for CEOs is positive, but relatively small. For example, Conyon (1997) and Ozkan (2011) found that the sensitivity between TRS and CEO pay is 0.061 and 0.095 for samples of British companies, respectively. In a similar vein, Hubbard and Palia (1995), Hartzell and Starks (2003), Cornett et al. (2009), and Li and Srinivasan (2011), respectively, report a PPS of 0.099, 0.093, 0.098 and 0.021 for samples of American firms. Our evidence also seems to provide support for the MPH, which suggests that in poorlygoverned firms, powerful CEOs tend to use their influence to design suboptimal incentive contracts that facilitates rent extraction, leading to small PPS.

Insert Table 6 about here.

Secondly, a second-tier agency conflict arises, whereby a suboptimal CEO pay package is approved by directors for a dominant $\mathrm{CEO}$ in return for some form of reciprocity from the CEO. To examine this secondary agency problem that occurs between directors and shareholders, we investigate the link between TEPAY and TRS by replacing CEPAY with TEPAY in equation (1). The coefficient of TRS on TEPAY in 
Model III of Table 6 is statistically significant and positive, but similarly small at 0.063 , and thereby providing new support for $H 1 b$. The economic meaning of this finding is that directors tend to reward powerful CEOs with overly generous pay packages in exchange for favourable director incentive terms from the CEO (Core et al., 2003; Morse et al., 2011). This can result in a culture of reciprocity in expropriating share owners wealth, and thereby equally leading to relatively small PPS. This conflict can particularly be exacerbated in South Africa where, under the second King Report proposals, the remuneration committee is required to seek the opinion of the $\mathrm{CEO}$ when deciding the pay of other executives. As a more direct and comparative test of the first- second-tier agency problems, we compare and test (see Table 7) the statistical significance of the estimated PPS coefficients between CEOs and all executive directors reported in Tables 6 and 8 to 13. As contained in Table 7, with the exception of the PPS coefficient reported in Panel $D$, step 1, the difference between CEOs and executives of all our estimates are statistically significant and positive, indicating that the PPS for CEOs is almost always significantly higher than that of all executive directors. This provides additional empirical support for $H 1 b$, as well as offers a new contribution to the existing research by suggesting that in a corporate setting of poor CG mechanisms and high levels of block shareholdings; the second-tier (monitoring power and opportunism of other directors) agency conflict is stronger than the first-tier (CEO power and opportunism) agency problem.

Insert Table 7 about here.

Third, our evidence so far suggests a positive, but relatively small PPS. Our total executive pay proxies are, however, made up of cash and equity-based pay. Therefore, to examine which component contributes most to the PPS, we re-estimate equation (1) by iteratively substituting TEPAY and CEPAY with their cash and non-cash alternatives, respectively. The respective coefficients of TRS on Cash and Non-cash-based pay in Models I and II for TEPAY, as well as those in Models IV and V for the CEPAY in Table 6 are all statistically significant and positive. Noticeably, and on average, the PPS appears stronger for equity-based than for cash-based pay. This offers empirical support for the suggestions of the second King Report and the results of past researchers (Jensen \& Murphy, 1990; Main et al., 1996; Ozkan, 2011), who found a higher PPS for CEO non-cash pay than CEO cash pay. The economic relevance of this evidence is that the structure rather than the level of pay seems to be more effective in influencing the PPS.

Fourth, and on comparative basis, the findings in Table 6 also indicate that irrespective of the pay measure used, the relationship between TRS and CEPAY seems to be stronger than that between TRS and 
TEPAY. This provides empirical support for the results of Mehran (1995) and Sapp (2008) for samples of American and Canadian firms, respectively. One reason is that CEOs carry out strategic and bigger roles with a greater chance of being sacked if corporate performance turned out to be poor compared with their managerial counterparts placed at lower levels (Kang \& Shivdasani, 1995; Dong, 2014; Guo et al., 2015). As a result, there is an expectation that CEOs will be paid higher, as well as their pay will be linked more closely to corporate performance as a reward for the additional risks and responsibilities that they generally assume compared with their lower placed colleagues.

\section{The moderating effect of $C E O$ power and CG structure on the PPS}

Our evidence so far suggests a positive, but relatively small PPS, which appears to provide support for the MPH. Central to the MPH, is the assumption that CEO commitment/CG is weak, which results in poor managerial monitoring and suboptimal incentive contracts. However, in better-governed firms with more committed CEOs, closer managerial monitoring can improve the PPS even if executive incentive contracts are somehow suboptimal. This suggests a complex modelling of the PPS, which takes into account the joint effect of both incentive alignment (executive pay) and monitoring (CEO power/CG structure) mechanisms on the PPS. Therefore, and in this sub-section, we distinctively investigate whether CEO power/CG structure can moderate the PPS with a fixed-effects regression model specified as follows:

$\operatorname{TEPAY}_{i t}=\alpha_{0}+\beta_{1}$TRS $_{i t-1}+\sum_{j=1}^{7} \beta_{j} \mathrm{CEO}_{i t-1}+\sum_{k=1}^{7} \beta_{k} I N T_{i t-1}+\sum_{l=1}^{10} \beta_{l}$ CONTROLS $_{i t-1} \cdot+\delta_{i t-1}+\varepsilon_{i t-1}$

where $\mathrm{CG}$ refers to the $\mathrm{CEO}$ power proxies, including $C E O A, C E O D, C E O O, C E O P, C E O R, C E O T$, $F C E O$ and $I N T$ refers to their respective interaction variables, namely $P^{*} C E O A, P^{*} C E O D, P * C E O O$, $P^{*} C E O P, P^{*} C E O R, P^{*} C E O T$ and $P^{*} F C E O$. Everything else remains the same as defined in equation (1). We also re-estimate equation (2) by replacing the CEO power proxies with their CG counterparts.

Thus, Tables 8 and 9 contain fixed-effects regression results examining the moderating effect of CEO power and CG mechanisms on the PPS, respectively. Models I to III in both tables report results relating to $T E P A Y$ for the $Q, O R O A$ and $T R S$ performance proxies, respectively, whilst Models IV to VI do similarly for the CEPAY alternative. First, and consistent with the findings in Models III and VI in Table 6, the coefficients of the TRS on TEPAY and CEPAY in Models III and VI in both tables are, respectively, statistically significant and positive. However, and most importantly, it is easily discernible that, 
irrespective of the executive pay proxy employed, the PPSs have considerably improved. This implies that CEO power and CG qualities appear to significantly moderate the PPS, a result which also seem to provide support for the OCT. For example, the PPS between TRS and CEPAY has improved from 0.095 in Model VI in Table 6 to 0.180 (0.155) in Model VI of Table 8 (9). While these statistically significant differences ( $p$-value <.01) are not significantly different in comparison with those found by previous researchers (Buck et al., 2008; Conyon \& He, 2011), it at least indicates that permitting for the presence of joint interactions among TEPAY, CEPAY, TRS, CEO power and governance structures leads to an increase in the PPS. Also, and on comparative basis, it is apparent from Table 8 (9) that the increase in the PPS is higher for CEPAY than for TEPAY. This is again consistent with our previous explanation that emphasised the strategic nature of the CEO role.

Insert Table 8 about here.

Insert Table 9 about here

Second, and with specific reference to the interaction variables, the findings reported in Table 8(9) generally provide evidence of a moderating effect of CEO power (CG structure) on the PPS, which is largely consistent with the predictions of the OCT, as well as our hypotheses. Specifically, the coefficients of $P^{*} C E O C, P^{*} C E O O, P^{*} C E O R$ and $P^{*} F C E O$ on TEPAY or CEPAY in Models III and VI of Table 8 are statistically significant, providing support for $H 2$. Similarly, the statistically significant and positive effect of $P^{*} B O W$ and $P^{*} D O W$ on TEPAY or CEPAY in Models III and VI of Table 9 provides support for $H 3$, whereas the statistically significant effect of $P^{*} B S I Z, P^{*} N C O$ and $P^{*} R C O$ on TEPAY or $C E P A Y$ in Models III and VI of Table 9 provides support for H4. Observably, our evidence contributes to a small, but gradually increasing number of international studies that suggest that board, CEO power and ownership structures can have a moderating effect on the PPS (Cornett et al., 2009; Finkelstein et al., 2009; Li \& Srinivasan, 2011; Wowak et al., 2011; Sanchez-Marin \& Baixauli-Soler, 2014).

\section{Additional analyses}

We conduct a number of additional analyses to further examine the robustness of our results. First, we check the robustness of our results by re-regressing equation (2) using $Q$ and $O R O A$ as alternative performance proxies to the TRS. The results presented in Models I and II relating to TEPAY based on the $Q$ and OROA, respectively, and similarly in Models IV and V relating to CEPAY in Tables 8 and 9 are 
qualitatively the same as those of the TRS in Models III and VI in the same tables, suggesting that our findings are robust to these alternative performance proxies.

Second, and so far we have estimated the PPS by taking into consideration the predictors, moderators and instruments simultaneously. One limitation of this approach is that it makes it difficult to assess the contributions of each category of variables. Therefore, and to ascertain the contributions of each category of variables to the estimated PPS, we employ a two-step multilevel ${ }^{1}$ (hierarchical) regression approach. Specifically, at the first step, we regress the instruments and predictors (governance and instrumented variables) on the compensation; and at the second step, we include the moderators (moderating variables) as additional explanatory variables. The results of our hierarchical (multilevel) regressions reported in Tables 10 and 11, respectively, for CEO power and CG structure suggest positive and statistically significant effect of PRE_TRS on TEPAY and CEPAY, respectively, and therefore implying that our results are fairly insensitive to estimating a hierarchical regression. However, the findings show that our moderating variables have some explanatory power, accounting roughly for between $8 \%$ and $12 \%$ $\left(\Delta R^{2}\right)$ of the variations in the estimated PPS.

\section{Insert Table 10 about here}

Insert Table 11 about here

Third, our sample period extends over the 2007/2008 global financial crisis. Thus, to ascertain whether executive pay differs over the period, we split the sample into two: pre- (2002 to 2006); and post- (2007 to 2012) 2007 financial crisis periods, and re-estimate equation (1), by including an additional dummy variable (D_FINCRISIS), which takes the value of 1 if the financial year is post-2007 (2007 to 2012) and 0 if the financial year is pre-2007 (2002 to 2006). Our full results, (which for brevity not reported here, but available on request), suggest a significant and positive coefficient (0.16) on the D_FINCRISIS. The economic interpretation of this evidence is that executive pay has increased in the pre-2007 period by about $16 \%(8 \%)$ in nominal (real - adjusted for 5\% SA annual inflation rate) terms.

Insert Table 12 about here.

Insert Table 13 about here

Finally, and to address causality and/or endogeneities that may arise from potential omitted variables bias, we employ the extensively applied two-stage least squares $(2 S L S)$ statistical technique. However, to

${ }^{1}$ We will like to thank an anonymous reviewer for this suggestion. 
make sure that the $2 S L S$ technique is appropriate, and following past studies (Beiner et al., 2006; Larcker \& Rusticus, 2010), we first conduct the Durbin-Wu-Hausman exogeneity test to test for the existence of an endogenous association between TRS and TEPAY or CEPAY. The null hypothesis of no endogeneity is rejected at the $1 \%$ level when the test is applied to equation (2), and we therefore, conclude that the $2 S L S$ technique is appropriate and that our fixed-effects results may be misleading and as such, requiring further investigation that follows.

The findings of several past studies (Beiner et al., 2006; Brown and Caylor, 2009) suggest that CEO power and CG structure variables do affect performance, and as such, in the first-stage, we assume that TRS will be determined by $7 \mathrm{CEO}$ power and $8 \mathrm{CG}$ structure mechanisms, as well as the 10 control variables. Therefore, the first-stage model to be estimated is specified as:

$$
T R R_{i t}=\alpha_{0}+\sum_{j=1}^{15} \beta_{j} C G_{-} C E O_{i t}+\sum_{k=1}^{10} \beta_{k} \text { CONTROLS }_{i t \bullet}+\varepsilon_{i t}
$$

Consistent with our predictions, the results, (which for brevity are not fully reported here, but available upon request), suggest statistically significant effect of the CEO power, CG structure and control variables on the TRS. Therefore, we re-regress equation (2) specified as:

$$
T E P A Y_{i t}=\alpha_{0}+\hat{\beta}_{1} P R E_{-} T R S_{i t}+\sum_{j=1}^{7} \beta_{j} C E O_{i t}+\sum_{k=1}^{7} \beta_{k} I N T_{i t}+\sum_{l=1}^{10} \beta_{l} \text { CONTROLS }_{i t}+\delta_{i t}+\varepsilon_{i t}
$$

where everything remains the same as defined in equation (2) except that we use the predicted TRS $\left(P R E \_T R S\right)$ from equation (3) as instrument for TRS. The $2 S L S$ results reported in Models III and VI of Tables 12 and 13, respectively, for CEO power and CG structure suggest positive and statistically significant effect of PRE_TRS on TEPAY and CEPAY, respectively, thereby implying that our results are fairly robust to potential causality and/or endogeneity problems that may arise from omitted variables. Additionally, the $2 S L S$ results based on $Q$ and $O R O A$ performance alternatives contained in Tables 12 and 13 remain positive and statistically significant, suggesting further that our findings are not significantly sensitive to potential causality and/or endogeneity problems.

\section{Summary and conclusion}

This study examines the crucial question of whether chief executive officer (CEO) power and governance (CG) mechanisms can moderate the pay-for-performance sensitivity (PPS) using a sample of 
169 South African publicly quoted companies from 2002 to 2012 . This coincides with a period during which the South Africa authorities introduced CG reforms that incorporated the presumption that executive pay will be closely tied to corporate performance. This permits us to distinctively examine the joint effects of incentive alignment (pay) and monitoring (CEO power and CG structure) mechanisms on the PPS using data on both total cash and equity-based CEO pay, as well as that of all executive directors. Our study, therefore, extends, as well as makes a number of new contributions to the extant theoretical and empirical literature.

First, previous studies examining direct links between executive pay and performance have generally reported a positive, but relatively small PPS (Gomez-Mejia \& Wiseman, 1997; Murphy, 1999; Tosi et al., 2000; van Essen et al., 2015). This appears to provide support for the managerial power hypothesis (MPH), which suggests that powerful executives use their influence to extract excessive rent through suboptimal incentive contracts. However, optimal contracting theory (OCT) predicts that in firms with strong governance and committed CEOs, greater monitoring can still improve the PPS even if executive incentive contracts are somehow suboptimal (Bertrand \& Mullainathan, 2001; Kuo et al., 2014). Prior studies, however, have seldom investigated the joint effects of incentive alignment and monitoring mechanisms on the PPS (Cornett et al., 2009; Finkelstein et al., 2009; Li \& Srinivasan, 2011; Wowak et al., 2011). In contrast, this paper distinctively investigates the more complex questions of why and how CEO and CG qualities can possibly moderate the PPS. Consistent with our predictions, the findings contribute to the literature by evidencing a positive, but relatively small PPS, and thereby providing support for the MPH. However, and in line with the predictions of the OCT, we also find that the PPS improves in firms with committed CEOs and strong governance. Specifically, we find that the PPS is higher in firms with more reputable, founding and shareholding CEOs, higher ownership by directors and institutions, and independent nomination and remuneration committees, but lower in firms with larger boards, more powerful, and long tenured CEOs.

Second, within the MPH, two distinct agency conflicts emerge when designing executive incentive contracts: primary and secondary (Bebchuk et al., 2002; Dong, 2014). The first-tier agency problem relates to the power that a CEO may have over the board in setting its own pay, which can facilitate excessive rent skimming through a suboptimal CEO incentive contract (Bebchuk \& Fried, 2003). The secondary agency problem concerns the apparent conflict of interests faced by directors in deciding both their own pay and 
that of the CEO, which can create a culture of mutual-favour, whereby an overly generous CEO incentive contract is approved by the board in return for favourable pay packages for the directors, and thereby equally leading to excessive rent extraction (Morse et al., 2011; Ding et al., 2015). Whilst the primary agency conflict has been extensively examined (Murphy, 1999; Frydman \& Jenter, 2010), the impact of the second-tier agency conflict on the PPS has rarely been investigated (Core et al., 2003). Our findings contribute to the literature by showing that the PPS for both the CEO and all executive directors is generally small, but comparatively strong in firms with committed CEOs and strong governance. In particular, our results make a new contribution to the literature by showing that in a corporate setting dominated by poor governance structures and block shareholdings; the first-tier agency conflict (CEO power and self-serving) is weaker than the second-tier agency problem (monitoring by other executive directors and self-interest).

Apart from our new empirical contributions, our findings also offer new insights and extensions to the OCT and MPH theories. Prior studies have often presented these two theories as competitors and as such, simply tested them in isolation; thereby failing to appreciate and identify their interconnectedness. Our findings show that whilst suboptimal pay contracts can result from powerful CEOs dominating pay setting institutions (e.g., the board and remuneration committee) and processes (as suggested by MPH), such agency conflicts can be reduced by contemporaneously strengthening CG structures (as suggested by OCT), and thereby equally leading to improved PPS. Methodologically, our findings imply that future researchers will need to commit to a more complex and dynamic instead of the traditional simple modelling of the PPS that is able to simultaneously incorporate both incentive alignment (pay) and monitoring (CG) mechanisms if their evidence is to be robust.

Third, our findings also have important policy, practitioner, regulatory and broader societal implications, especially for companies and authorities in other developing countries that are contemplating or currently pursuing CG and executive pay policy reforms. A key implication of our evidence is that for greater effectiveness, incentive alignment (executive pay) and monitoring (CG) policy reforms should be jointly pursued. For example, in order to obtain maximum impact, a recommendation for equity-based pay to constitute a substantial portion of total executive pay in order to align executive interests with those of shareholders should be accompanied by equivalent CG reforms that seek to: (i) strengthen board independence by encouraging relatively smaller boards that are supported by properly constituted and 
functioning independent sub-committees, such as nomination and remuneration committees; (ii) promote greater institutional shareholding and activism; and (iii) stimulate ownership by directors. Additionally, our evidence implies that efforts by policy-makers, practitioners, regulators and broader society at improving good governance in general, and the PPS in particular, should not only focus on reducing concentration of power (e.g., discouraging entrenchment through long tenure) and increasing financial interests (e.g., encouraging ownership) among CEOs/senior executives, but also encouraging strong nonfinancial/emotional (e.g., founder status and public reputation for good governance/performance) attachments to their firms. Methodologically, our evidence implies that scholars seeking to robustly model the PPS, should not only consider traditional measures (e.g., performance and size), but also non-traditional factors (e.g., CEO power, board and ownership structures) within a joint estimation framework.

Finally, whilst the findings reported are significant and reliable, its limitations need to be explicitly acknowledged. As a result of lack of data, we limited our analysis to a small number of internal CG structures and, as more data becomes available, researchers may consider collecting data not just on internal governance mechanisms, such as board size and independent directors, but external governance structures, such as the labour, capital and corporate control markets when calculating the PPS. Like all archival studies of this nature, our variables employed as measures for performance, CEO power and CG structures may or may not represent how boards, executives and shareholders operate in practice. For example, past studies have shown that it is the role (e.g., active or passive) rather than the extent of institutional ownership per se that can impact positively on governance and pay structures (Gillan \& Starks, 2003; Hartzell \& Starks, 2003; Almazan et al., 2005). However, due to data limitations, we have not been able to divide our institutional ownership measure into active, passive, long-term and short-term investors and thus, future researchers may build on or extend our results by investigating their impact on the PPS. As we focus only on South Africa, generalisability of our findings are arguably limited and hence, future studies may be able to provide new insights by applying our framework to a cross-country data, especially from developing countries in Africa, America, Asia and Europe. Methodologically, more nuanced insights may be gained by future scholars by conducting in-depth interviews with boards, executives and owners relating to $\mathrm{CG}$, pay and the PPS. 


\section{References}

Alman, A., Hartzell, J.C., \& Starks, L.T. (2005). Active institutional shareholders and costs of monitoring: Evidence from executive compensation. Financial Management, 34(4), 5-34.

Angel, P.O., \& Fumas, V.S. (1997). The compensation of Spanish executives: A test of a managerial talent model, International Journal of Industrial Organization, 15(4), 511-531.

Armstrong, Philip, Segal, Nick, \& Davis, B. (2006) Corporate governance in South Africa. In: C.A. Mallin (Eds) Handbook on international corporate governance, pp.210-231 (Cheltenham: Edward Elgar Publishing).

Balafas, N., \& Florackis, C. (2014). CEO compensation and future shareholder returns: Evidence from the London Stock Exchange. Journal of Empirical Finance, 27, 97-115.

Bebchuk L.A., \& Fried, J.M. (2004). Pay without performance, (Cambridge: Harvard University Press).

Bebchuk L.A., \& Grinstein, Y. (2005). The growth of executive pay. Oxford Review of Economic Policy, 21(2), 283-303.

Bebchuk L.A., \& Weisbach, M.S. (2010). The state of corporate governance research. Review of Financial Studies, 23(2), 939-961.

Bebchuk, L.A., \& Fried, J.M. (2003). Executive compensation as an agency problem. Journal of Economic Perspectives, 17(3), 71-92.

Bechuk, L.A., Fried, J.M., \& Walker, D.I. 2002. Managerial power and rent extraction in the design of executive compensation. University of Chicago Law Review, 69, 751-846.

Beiner, S., Drobetz, W., Schmid, M.M., \& Zimmermann, H. (2006). An integrated framework of corporate governance and firm valuation. European Financial Management, 12(2), 249-283.

Benito, A., \& Conyon, M.J. (1999). The governance of directors' pay: Evidence from UK companies. Journal of Management \& Governance, 3(2), 117-136.

Berrone, P., Makri, M., \& Gomez-Mejia, L.R. (2008). Executive compensation in North American hightechnology firms: A contextual approach. International Journal of Human Resource Management, 19, 1534-1552.

Bertrand, M., \& Mullainathan, S. (2001). Are CEOS rewarded for luck? The ones without principals are. Quarterly Journal of Economics, 116(3), 901-932.

Blanco, M.R. \& Golik, M.N. (2015). Born under a lucky star? Latin American CEOs' perceptions about their own career development. International Journal of Human Resource Management, 26(14), 18651888.

Bloom, M., Milkovich, G.T., \& Mitra, A. (2003). International compensation: Learning from how managers respond to variations in local host contexts. International Journal of Human Resource Management, 14(8), 1350-1367.

Bonache, J. \& Fernandez, Z. (1997). Expatriate compensation and its link to the subsidiary strategic role: A theoretical analysis. International Journal of Human Resource Management, 8(4), 457-475.

Brown, L.D., \& Caylor, M.L. (2009). Corporate governance and firm operating performance. Review of Quantitative Finance and Accounting, 32(2), 129-144.

Buck, Trevor, Liu, Xiaohui, \& Skovoroda, R. (2008). Top executive pay and firm performance in China, Journal of International Business Studies, 39, 833-850.

Chahine, S., \& Goergen, M. (2011). The two sides of the CEO option grants at the IPO. Journal of Corporate Finance, 17, 1116-1131.

Chen, J., Ezzamel, M., \& Cai, Z. (2011). Managerial power theory, tournament theory, and executive pay in China. Journal of Corporate Finance, 17(4), 1176-1199.

Cheng, S., \& Firth, M. (2005). Ownership, corporate governance and top management pay in Hong Kong. Corporate Governance: An International Review, 13(2), 291-302.

Chhaochharia, V., \& Grinstein, Y. (2009). CEO compensation and board structure. Journal of Finance, 64(1), 231-261.

Cho, K.R., Huang, C.-H., \& Padmanabhan, P. (2014). Foreign ownership mode, executive compensation structure, and corporate governance: Has the literature missed an important link? Evidence from Taiwanese firms. International Business Review, 23(2), 371-380.

Claessens, S.B. \& Yurtoglu, B. (2013). Corporate governance in emerging markets: A survey. Emerging Markets Review, 15, 1-33.

Conyon, M.J. (1997). Corporate governance and executive compensation. International Journal of Industrial Organization, 15(4), 493-509. 
Conyon, M.J., \& He, L. (2011). Executive compensation and corporate governance in China. Journal of Corporate Finance, 17(4), 1158-1175.

Conyon, M.J., \& He, L. (2012). CEO compensation and corporate governance in China. Corporate Governance: An International Review, 20(6), 575-592.

Conyon, M.J., \& Murphy, K.J. (2000). The prince and the pauper? CEO pay in the United States and United Kingdom. Economic Journal, 110(467), 640-671.

Core, J.E., Guay, W.R., Larcker, D.F. (2003). Executive equity compensation: A survey. Economic Policy Review, 9(1), 7-50.

Core, J.E., Holthausen, R.W., \& Larcker, D.F. (1999). Corporate governance, chief executive officer compensation, and firm performance. Journal of Financial Economics, 51(3), 371-406.

Cornett, M.M., McNutt, J.J., \& Tehranian, H. (2009). Coporate governance and earnings management at large U.S. bank holding companies. Journal of Corporate Finance, 15, 412-430.

DeVaro, J., \& Fung, S. (2014). Public bailouts, executive compensation and retention: A structural analysis. Journal of Empirical Finance, 26, 131-149.

Dharwadkar, B., George, G., \& Brandes, P. (2000). Privatization in emerging economies: An agency theory perspective. Academy of Management Review, 25, 650-669.

Ding, D.Z, Akhtar, S., \& Ge, G.L. (2006). Organizational differences in managerial compensation and benefits in Chinese firms. International Journal of Human Resource Management, 17(4), 693-715.

Ding, S., Jia, C., Wilson, C., \& Wu, Z. (2015). Political connections and agency conflicts: The roles of owner and manager political influence on executive compensation. Review of Quantitative Finance and Accounting, 45, 407-434.

Ding, S., Jia, C., Wu, Z., \& Zhang, X. (2014). Executive political connections and firm performance: Comparative evidence from privately-controlled and state-owned enterprises. International Review of Financial Analysis, 36, 153-167.

Dong, G.N. (2014). Excessive financial services CEO pay and financial crisis: Evidence from calibration estimation. Journal of Empirical Finance, 27, 75-96.

Dong, M., \& Ozkan, A. (2008). Institutional investors and director pay: An empirical study of UK companies. Journal of Multinational Financial Management, 18(1), 16-29.

Dong, Z., Wang, C., \& Xie, F. (2010). Do executive stock options induce excessive risk taking? Journal of Banking Finance, 34(10), 2518-2529.

Finkelstein, S., Hambrick, D.C., \& Cannella, A. A. (2009). Strategic leadership: Theory and research on executives, top management teams, and boards. New York: Oxford University Press.

Firth M., Fung, P.M.Y., \& Rui, O.M. (2007). How ownership and corporate governance influence chief executive pay in China's listed firms. Journal of Business Research, 60(7), 776-785.

Firth, M., Fung, P.M.Y., \& Rui, O.M. (2006). Corporate performance and CEO compensation. Journal of Corporate Finance, 12(4), 693-714.

Frydman, C., \& Jenter, D, (2010). CEO compensation. Annual Review of Financial Economics, 2(1), 75102.

Frydman, C., \& Saks, R.E. (2010). Executive compensation: A new view from long-run perspective, Review of Financial Studies, 23(5), 2099-2138.

Gil-Alana, L.A., Iniguez-Sanchez, R., \& Lopez-Espinosa, G. (2011). Endogenous problems in crosssectional valuation models based on accounting information. Review of Quantitative Finance and Accounting, 37(2), 245-265.

Gillan, S., \& Starks, L. (2003). Corporate governance, corporate ownership, and the role of institutional investors: A global perspective. Journal of Applied Finance, 13(2), 4-22.

Goergen, M., \& Renneboog, L. (2011). Managerial compensation. Journal of Corporate Finance, 17(4), 1068-1077.

Gomez-Mejia, L.R., Tosi, H., \& Hinkin, T. (1987). Managerial control, performance and executive compensation. Academy of Management Journal, 30(1), 51-70.

Gomez-Mejia, L.R., \& Wiseman, R.M. (1997). Reframing executive compensation: An assessment and outlook. Journal of Management, 23, 291-374.

Guo, L, Jalal, A., \& Khaksari, S. (2015). Bank executive compensation structure, risk taking and the financial crisis. Review of Quantitative Finance and Accounting, Forthcoming.

Hartzell, J.C., \& Starks, L.T. (2003). Institutional investors and executive compensation. Journal of Finance, 58(6), 2351-2374.

He, L., Wan, H., \& Zhou, X. (2014). How are political connections valued in China? Evidence from market reaction to CEO succession. International Review of Financial Analysis, 36, 141-152. 
Hubbard, G.R., \& Palia, D. (1995). Executive pay and performance: Evidence from the US banking industry. Journal of Financial Economics, 39(1), 105-130.

Jensen, M.C., \& Meckling, W.H. (1976). Theory of the firm: managerial behaviour, agency costs and ownership structure. Journal of Financial Economics, 12(4), 235-360.

Jensen, M.C., Murphy, K.J. (1990). Performance pay and top-Management incentives. Journal Political Economy, 98(2), 225-264.

Jimenez-Angueira, C.E., \& Stuart, N.V. (2015). Relative performance evaluation, pay-for-luck, and doubledripping in CEO compensation. Review of Quantitative Finance and Accounting, 44, 701-732.

Jones, D., \& Kato, T. (1996). The determinants of chief executive compensation in transitional economies: Evidence from Bulgaria. Labour Economics, 3(3), 305-360.

Jones, R.A., \& Wu, Y.W. (2010). Executive compensation, earnings management and shareholder litigation, Review of Quantitative Finance and Accounting, 35(1), 1-20.

Kale, J.R., Reis, E., \& Venkateswaran, A. (2014). Pay inequalities and managerial turnover. Journal of Empirical Finance, 27, 21-29.

Kang, J-K., \& Shivdasani, A. (1995). Firm performance, corporate governance, and top executive turnover in Japan. Journal of Financial Economics, 38, 29-58.

Kaplan, S. (1994). Top executives, turnover and firm performance in Germany. Journal of Law, Economics and Organization, 10(1), 142-159.

Kato, T.K., \& Long, C.X. (2006). Executive compensation, firm performance and corporate governance in China: Evidence from listed firms in the Shanghai and Shenzhen stock exchanges. Economic Development and Cultural Change, 54, 945-983.

King Committee (1994, 2002, 2010). King reports on corporate governance for South Africa, (Johannesburg: Institute of Directors).

Kumar, V.A., \& Kaura, M.H. (2002). Executive compensation and corporate performance: An EVA approach, South Asian Journal of Management, 9, 12-20.

Kuo, H.-C., Lin, D., Lin, D., Wang, L.-H., \& Yeh, L.-J. (2014). Is there an inverse U-shaped relationship between pay and performance? North American Journal of Economics and Finance, 28, 347-357.

La Porta, R., López-de-Silanes, F., \& Shleifer, A., (1999). Corporate ownership around the world. Journal of Finance, 54(2), 471-517.

La Porta, R., López-de-Silanes, F., \& Shleifer, A., (2002). Investor protection and corporate valuation. Journal of Finance, 57(3), 1147-1170.

La Porta, R., López-de- Silanes, F., Shleifer, A., \& Vishny, R., (2000). Investor protection and corporate governance. Journal of Financial Economics, 58(1-2), 3-27.

Larcker, D.F., \& Rusticus, T.O. (2010). On the use of instrumental variables in accounting research. Journal of Accounting and Economics, 49(3), 186-205.

Lee, K.W., Lev, B., \& Yeo, G.H.H. (2008). Executive pay dispersion, corporate governance, and firm performance. Review of Quantitative Finance and Accounting, 30(3), 315-338.

Lee, M.B., Scarpello, V., \& Rockmore, B.W. (1995). Strategic compensation in South Korea's publicly traded firms. International Journal of Human Resource Management, 6(3), 686-701.

Li, F., \& Srinivasan, S. (2011). Corporate governance when founders are directors. Journal of Financial Economics, 102, 454-469.

Lin, Y-F. (2005). Corporate governance, leadership structure and CEO compensation: Evidence from Taiwan. Corporate Governance: An International Review, 13(6), 824-835.

Lippert, R., \& Porter, G. (1997). Understanding CEO pay: A test of two pay-to-performance sensitivity measures with alternative measures of alignment and influence. Journal of Business Research, 40(2), 127-138.

Main, B.G.M., Bruce A., \& Buck, T. (1996). Total board remuneration and company performance. Economic Journal, 106(439), 1627-1644.

Malherbe, S., \& Segal, N. (2003). South Africa: after apartheid, in: C. P. Oman (Eds), Corporate governance in development, the experiences of Brazil, Chile, India, and South Africa, pp.248-251 (Washington: OECD).

McKnight, P.J., \& Tomkins, C. (1999). Top executive pay in the United Kingdom: A corporate governance dilemma. International Journal of the Economics of Business, 6(2), 223-243.

Mehran, H. (1995). Executive compensation structure, ownership, and firm performance. Journal of Financial Economics, 38(2), 163-184.

Merhebi, R., Pattenden, K., Swan, P.L., \& Zhou, X. (2006). Australian chief executive officer remuneration: pay and performance, Accounting and Finance, 46(3), 481-497. 
Morck, R., Shleifer, A. \& Vishny, R.W. (1988). Management ownership and market valuation: An empirical analysis. Journal of Financial Economics, 20, 293-315.

Morse, A., Nanda, V., \& Seru, A. (2011). Are incentive contracts rigged by powerful CEOs? Journal Finance, 66(5), 1779-1821.

Murphy, K.J. (1985). Corporate performance and managerial remuneration: An empirical investigation, Journal of Accounting and Economics, 7(1-3), 11-42.

Murphy, K.J. (1999). Executive compensation. In: O. Ashenfelter and D. Card (Eds) Handbook of labor economics, pp.2485-2563 (Amsterdam: North-Holland).

Ntim, C.G, Opong, K.K., \& Danbolt, J. (2012a). The relative value relevance of shareholder versus stakeholder corporate governance disclosure policy reforms in South Africa. Corporate Governance: An International Review, 20(1): 84-105.

Ntim, C.G., Lindop, S., \& Thomas, D.A. (2013). Corporate governance and risk reporting in South Africa: A study of corporate risk disclosures in the pre- and post-2007/2008 global financial crisis periods. International Review of Financial Analaysis. 30, 363-383.

Ntim, C.G., Lindop, S., Osei, K.A., \& Thomas, D.A. (2015). Executive compensation, corporate governance and corporate performance: A simultaneous equation approach. Managerial and Decision Economics, 36, 67-96.

Ntim, C.G., Opong, K.K., Danbolt, J., \& Thomas, D.A. (2012b). Voluntary corporate governance disclosures by post-apartheid South African corporations. Journal of Applied Accounting Research, 13(2), 122-144.

Ozkan, N. (2011). CEO compensation and firm performance: An empirical investigation of UK panel data, European Financial Management, 17(2), 260-285.

Peng, M.W., Wang, D.Y.L., \& Jiang, Y. (2008). An institution-based view of international business strategy: A focus on emerging economies. Journal of International Business Studies, 39, 920-936.

Pepper, A., Gore, J., \& Crossman, A. (2013). Are long-term incentive plans an effective and efficient way of motivating senior executives? Human Resource Management Journal, 23(1), 36-51.

Petersen, M.A. (2009). Estimating standard errors in finance panel data sets: Comparing approaches. Review of Financial Studies, 22(1), 435-480.

Reddy, K., Abidin, S., \& You, L. (2015). Does corporate governance matter in determining CEO compensation in the publicly listed companies in New Zealand? An empirical investigation. Managerial Finance, 41(3), 301-327.

Romero, M.G. \& Cabrera, R.V. (2001). Strategy and managers' compensation: The Spanish case. International Journal of Human Resource Management, 12(2), 218-242.

Sanchez-Marin, G. \& Baixauli-Soler, J.S. (2014). CEO reputation and top management team compensation. Management Decision, 52(3), 540-558.

Sanchez-Marin, G., Baixauli-Soler, J.S., \& Lucas-Perez, M.E. (2010). When much is not better? Top management compensation, board structure, and performance in Spanish firms. International Journal of Human Resource Management, 21(15), 2778-2797.

Sapp, S.G. (2008). The impact of corporate governance on executive compensation. European Financial Management, 14(4), 710-746.

Sarra J.P. (2004). Strengthening domestic corporate activity in global capital markets: A Canadian perspective on South Africa's corporate governance. GWU Law School Public Law Research Paper No. 118, University of British Columbia, Vancouver.

Schaefer, S. (1998). The dependence of pay-performance sensitivity on the size of the firm. Review of Economic Statistics, 80(3), 436-443.

Sun, J., \& Cahan, S. (2009). The effect of compensation committee quality on the association between CEO cash compensation and accounting performance. Corporate Governance: An International Review, 17(2), 193-207.

Tien, C. \& Chen, C.-.N. (2012). Myth or reality? Assessing the moderating role of CEO compensation on the momentum of innovation in R\&D. International Journal of Human Resource Management, 23(13) 2763-2784.

Tosi, H.L., Werner, S., Katz, J.P., \& Gomez-Mejia, L. R. (2000). How much does performance matter? A meta-analysis of CEO pay studies. Journal of Management, 26, 301-339.

Upneja, A., \& Ozdemir, O. (2014). Compensation practices in the lodging industry: Does top management pay affect corporate performance? International Journal of Hospitality Management, 30, 30-38. 
van Essen, Otten, J., \& Carberry, E.J. (2015). Assessing managerial power theory: A meta-analytic approach to understanding the determinants of CEO Compensation. Journal of Management, 41, 164202.

Vefeas, N. (1999). The nature of board nominating committees and their role in corporate governance. Journal of Business Finance and Accounting, 26(1-2), 199-225.

Wowak, A.J., Hambrick, D.C., \& Henderson, A.D. (2011). Do CEOs encounter within-tenure settling up? A multiperiod perspective on executive pay and dismissal. Academy of Management Journal, 54, 719739.

Young, M.N., Peng, M.W., Ahlstrom, D., Bruton, G.D., \& Jiang, Y. (2008). Corporate governance in emerging economies: A review of the principal-principal perspective. Journal of Management Studies, 45, 196-220.

Zheng, Y. (2010). Heterogenous institutional investors and CEO compensation. Review of Quantitative Finance and Accounting, 35(1), 21-46.

Table 1. A summary of director remuneration policy reforms contained in the King I and II reports

\begin{tabular}{|c|c|c|}
\hline Remuneration provision & 1994 King Report (King I) & 2002 King Report (King II) \\
\hline $\begin{array}{c}\text { Philosophy of remuneration: } \\
\text { Remuneration policy } \\
\text { Rationale/basis }\end{array}$ & $\begin{array}{l}\text { Not specified } \\
\text { Not specified }\end{array}$ & $\begin{array}{l}\text { Required to be stated } \\
\text { Required to be stated }\end{array}$ \\
\hline $\begin{array}{l}\text { Remuneration committee: } \\
\text { Committee } \\
\text { Composition } \\
\text { Chairperson } \\
\text { Charter/terms of reference } \\
\text { Performance evaluation } \\
\end{array}$ & $\begin{array}{l}\text { Required to be established } \\
\text { Not specified } \\
\text { Not specified } \\
\text { Not specified } \\
\text { Not specified }\end{array}$ & $\begin{array}{l}\text { Required to be established } \\
\text { Only independent directors } \\
\text { Independent director } \\
\text { Required to be stated } \\
\text { On an annual basis }\end{array}$ \\
\hline $\begin{array}{l}\text { Nomination committee: } \\
\text { Committee } \\
\text { Composition } \\
\text { Chairperson } \\
\text { Charter/terms of reference } \\
\text { Performance evaluation } \\
\end{array}$ & $\begin{array}{l}\text { Not specified } \\
\text { Not specified } \\
\text { Not specified } \\
\text { Not specified } \\
\text { Not specified } \\
\end{array}$ & $\begin{array}{l}\text { Required to be established } \\
\text { Majority independent dtors. } \\
\text { Independent director } \\
\text { Required to be stated } \\
\text { On an annual basis }\end{array}$ \\
\hline $\begin{array}{l}\text { Remuneration structure: } \\
\text { Cash-based } \\
\text { Equity-based } \\
\text { Proportion } \\
\end{array}$ & $\begin{array}{l}\text { Not specified } \\
\quad \text { Not specified } \\
\text { Not specified }\end{array}$ & $\begin{array}{l}\text { Required to be specified } \\
\text { Required to be specified } \\
\text { Equity-based should be greater }\end{array}$ \\
\hline $\begin{array}{l}\text { Remuneration approval: } \\
\text { Remuneration committee } \\
\text { Board } \\
\text { Shareholders/AGM } \\
\end{array}$ & $\begin{array}{l}\text { Recommend remuneration level } \\
\text { Required to approve } \\
\text { Not specified }\end{array}$ & $\begin{array}{l}\text { Recommend remuneration level } \\
\text { Required to approve } \\
\text { Has final approving authority }\end{array}$ \\
\hline $\begin{array}{l}\text { Shareholder activism: } \\
\text { Encouragement } \\
\text { Questioning } \\
\text { Shareholder consultation }\end{array}$ & $\begin{array}{l}\text { Not specified } \\
\text { Not specified } \\
\text { Not specified }\end{array}$ & $\begin{array}{l}\text { Explicitly encouraged } \\
\text { Questions to the chair } \\
\text { Major institutional shareholders }\end{array}$ \\
\hline $\begin{array}{l}\text { Remuneration disclosure: } \\
\text { Executive/CEO } \\
\text { Non-executive } \\
\text { Independent } \\
\text { Frequency } \\
\text { Medium } \\
\text { Details/items } \\
\text { Committee membership } \\
\text { Meetings/attendance }\end{array}$ & $\begin{array}{l}\text { Not specified } \\
\text { Note specified } \\
\text { Not specified } \\
\text { Not specified } \\
\text { Not specified } \\
\text { Not specified } \\
\text { Not specified } \\
\text { Not specified } \\
\end{array}$ & $\begin{array}{l}\text { On an individual basis } \\
\text { On an individual basis } \\
\text { On an individual basis } \\
\text { On an annual basis } \\
\text { Annual report } \\
\text { All: cash and equity-based } \\
\text { On an individual basis } \\
\text { On an individual basis }\end{array}$ \\
\hline Compliance or regulation & Voluntary or self-regulation & Voluntary or self-regulation \\
\hline
\end{tabular}


Table 2. Summary of sampling procedure

\begin{tabular}{lcc}
\hline $\begin{array}{l}\text { Industrial composition of the total non-financial firms quoted } \\
\text { on the Stock Exchange available to be sampled as at 31/12/2012 }\end{array}$ & $\begin{array}{c}\text { No. in each } \\
\text { industry }\end{array}$ & $\begin{array}{c}\text { Percentage } \\
\text { of sample }\end{array}$ \\
\hline Industrials & 81 & 27.8 \\
Basic materials & 67 & 23.0 \\
Consumer services & 62 & 21.3 \\
Consumer goods & 36 & 12.4 \\
Technology & 31 & 10.7 \\
Health care & 7 & 2.4 \\
Telecommunications & 4 & 1.4 \\
Oil and gas & 3 & 1.0 \\
Total firms available to be sampled & 291 & 100.0 \\
$\quad$ Less: Firms with no year's data available & & \\
$\quad$ Firms with some years' data missing & 122 & 41.9 \\
Total sampled firms with full data included in study & 169 & 58.1 \\
\hline Industrial composition of & No. in each \\
sampled firms with full data & industry & Percentage \\
\hline Industrials & 51 & 30.2 \\
Consumer services & 35 & 20.7 \\
Basic materials & 33 & 19.5 \\
Consumer goods & 24 & 14.2 \\
Technology & 19 & 11.2 \\
Health care & 3 & 1.8 \\
Telecommunications & 3 & 1.8 \\
Oil and gas & 1 & 0.6 \\
Total sampled firms with full data included in study & 169 & 100.0 \\
\hline Source: South Afira & & \\
\hline
\end{tabular}

Source: South African Stock Exchange. 
Table 3. Measures and variables definition summaries

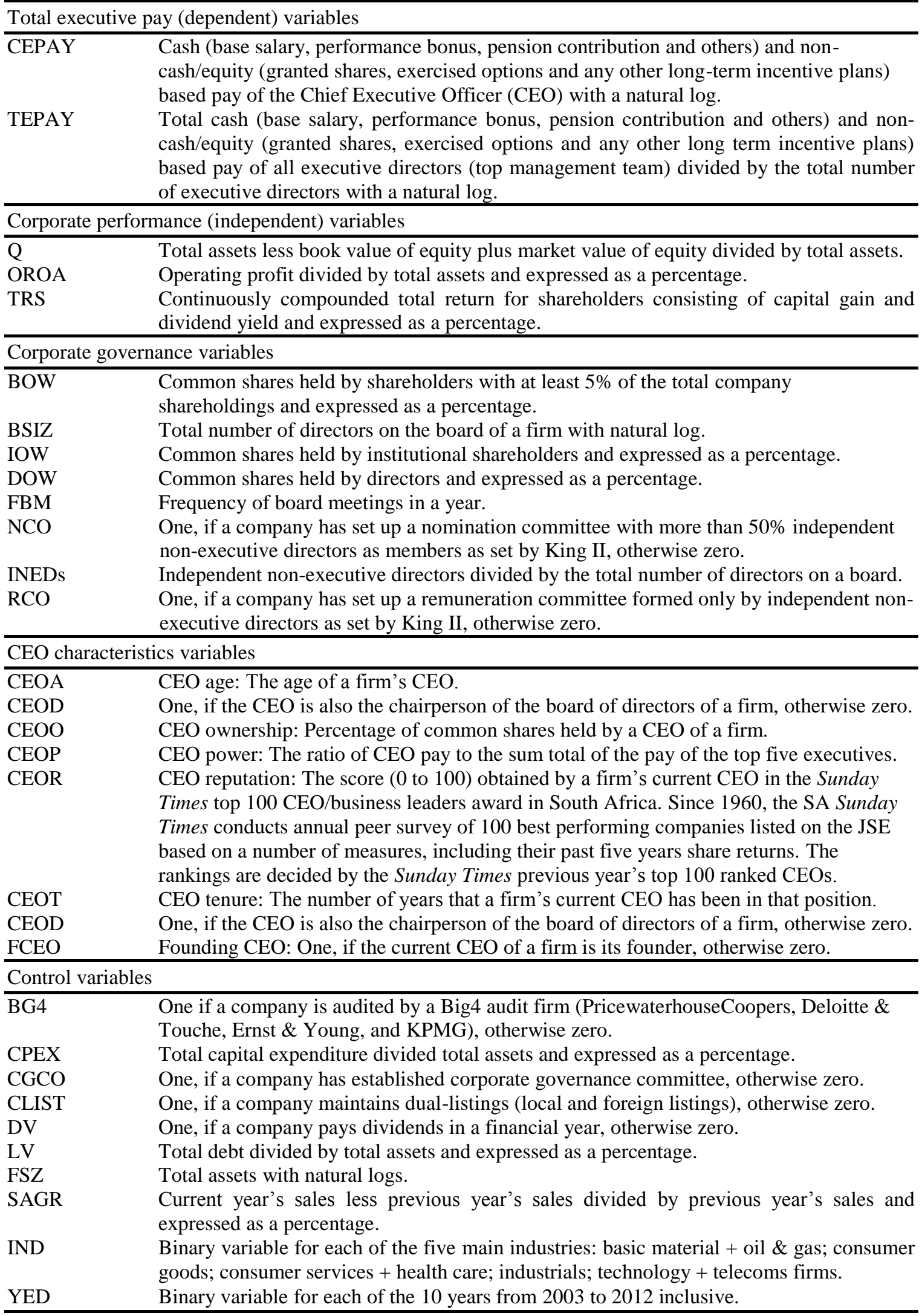


Table 4. Descriptive statistics of all variables for all $(1,690)$ firm years.

\begin{tabular}{|c|c|c|c|c|c|}
\hline Variable & Mean & Median & Std. dev. & Maximum & Minimum \\
\hline \multicolumn{6}{|c|}{ Group A: Total executive (top management team) pay (dependent) variables } \\
\hline$\overline{C E O C A S H(R m)}$ & 2.18 & 1.37 & 2.97 & 13.18 & 0.06 \\
\hline CEO EQUITY $(\mathrm{Rm})$ & 0.75 & 0.44 & 0.88 & 3.80 & 0.00 \\
\hline CEPAY $(R m)$ & 2.89 & 1.78 & 3.79 & 16.86 & 0.06 \\
\hline TEPAY CASH $(\mathrm{Rm})$ & 11.28 & 6.94 & 11.36 & 74.79 & 0.11 \\
\hline$T E P A Y \operatorname{EQUITY}(\mathrm{Rm})$ & 1.66 & 0.98 & 1.98 & 12.40 & 0.00 \\
\hline TEPAY $(R m)$ & 12.92 & 7.86 & 13.74 & 87.54 & 0.11 \\
\hline \multicolumn{6}{|c|}{ Group B: Corporate performance (independent) variables } \\
\hline $\bar{Q}$ & 1.58 & 1.38 & 0.72 & 3.60 & 0.72 \\
\hline OROA $(\%)$ & 10.79 & 11.95 & 14.10 & 37.85 & -19.34 \\
\hline $\operatorname{TRS}(\%)$ & 28.38 & 25.24 & 88.73 & 236.42 & -48.29 \\
\hline \multicolumn{6}{|c|}{ Group C: CEO power variables } \\
\hline$\overline{C E O A}$ & 52.94 & 53.00 & 9.11 & 81.00 & 34.00 \\
\hline$C E O D$ & 0.23 & 0.00 & 0.43 & 1.00 & 0.00 \\
\hline CEOO (\%) & 8.59 & 7.43 & 9.86 & 67.85 & 0.03 \\
\hline CEOP & 0.48 & 0.44 & 0.42 & 0.80 & 0.05 \\
\hline CEOR & 29.86 & 26.00 & 33.31 & 100.00 & 0.00 \\
\hline CEOT & 7.36 & 6.80 & 8.09 & 42.00 & 0.25 \\
\hline FCEO & 0.19 & 0.17 & 0.28 & 1.00 & 0.00 \\
\hline \multicolumn{6}{|c|}{ Group D: Corporate governance structure variables } \\
\hline$\overline{B O W(\%)}$ & 62.43 & 64.74 & 18.50 & 91.80 & 10.21 \\
\hline$B S I Z$ & 9.80 & 10.00 & 3.73 & 18.00 & 4.00 \\
\hline DOW $(\%)$ & 19.32 & 88.79 & 18.34 & 78.84 & 1.42 \\
\hline$I O W(\%)$ & 74.32 & 82.26 & 22.90 & 97.69 & 9.42 \\
\hline$F B M$ & 4.77 & 4.00 & 2.42 & 16.00 & 1.00 \\
\hline $\mathrm{NCO}$ & 0.28 & 0.00 & 0.38 & 1.00 & 0.00 \\
\hline INEDs $(\%)$ & 56.90 & 57.74 & 15.48 & 84.28 & 17.36 \\
\hline$R C O$ & 0.14 & 0.00 & 0.35 & 1.00 & 0.00 \\
\hline \multicolumn{6}{|c|}{ Group E: Control variables } \\
\hline$\overline{B G 4}$ & 0.73 & 1.00 & 0.44 & 1.00 & 0.00 \\
\hline СРЕX (\%) & 12.95 & 8.64 & 15.38 & 66.50 & 7.28 \\
\hline$C G C O$ & 0.32 & 0.00 & 0.47 & 1.00 & 0.00 \\
\hline CLIST & 0.22 & 0.00 & 0.41 & 1.00 & 0.00 \\
\hline$D V$ & 0.67 & 1.00 & 0.47 & 1.00 & 0.00 \\
\hline$L V(\%)$ & 17.76 & 16.36 & 13.70 & 55.92 & 5.13 \\
\hline$F S Z$ & 5.94 & 6.10 & 0.56 & 7.88 & 4.24 \\
\hline SAGR (\%) & 12.35 & 13.98 & 26.53 & 89.58 & -44.21 \\
\hline
\end{tabular}

Notes: Variables are defined as follows: CEO total cash-based pay (CEO CASH) in millions of SA Rands ( $R$ in millions), CEO total equity-based pay (CEO EQUITY), CEO total pay (CPAY), total cash-based pay of all executive directors (TPAY CASH), total equitybased pay of all executive directors (TPAY EQUITY), total pay of all executive directors (TPAY), Tobin's Q $(Q)$, operating return on assets $(O R O A)$, total return for shareholders (TRS), CEO age (CEOA), CEO duality (CEOD), CEO ownership (CEOO), CEO power $(C E O P)$, CEO reputation (CEOR), CEO tenure (CEOT), CEO duality (CEOD), founding CEO (FCEO), block ownership $(B O W)$, board size $(B S I Z)$, director ownership $(D O W)$, institutional ownership $(I O W)$, the number of board meetings $(F B M)$, the presence of an independent nomination committee $(N C O)$, the percentage of independent non-executive directors (INEDs), the presence of an independent remuneration committee $(R C O)$, audit firm size $(B G 4)$, capital expenditure $(C P E X)$, the presence of a CG committee $(C G C O)$, cross-listing $(C L I S T)$, dividend payment status $(D V)$, leverage $(L V)$, firm size $(F S Z)$, and sales growth $(S A G R)$. 
Table 5. Pearson's and Spearman's correlation matrices of the variables for all 1,690 firm years

\begin{tabular}{|c|c|c|c|c|c|c|c|c|c|c|c|c|c|c|c|c|c|c|c|c|}
\hline Variable & TEPAY & CEPAY & $T R S$ & CEOA & CEOP & CEOO & CEOR & CEOT & CEOD & $F C E O$ & $B O W$ & $B S I Z$ & DOW & $I O W$ & $\mathrm{NCO}$ & INEDs & $R C O$ & $L V$ & $F S Z$ & SAGR \\
\hline TEPAY & 1.00 & $.74^{* * *}$ & $.13^{* *}$ & .05 & $.40^{* * * *}$ & -.07 & $.28^{* * * *}$ & $.10^{*}$ & .01 & $.11^{* *}$ & $.12^{* *}$ & $.28^{* * * *}$ & $-.15^{* * *}$ & $-.23^{* * * *}$ & $-.21^{* * * *}$ & $-.24^{* *}$ & $-.28^{* * * *}$ & $-.23^{* * * *}$ & $.45^{* * *}$ & $.11^{* *}$ \\
\hline CEPAY & $.69^{* * * *}$ & 1.00 & $.15^{* *}$ & $.08^{*}$ & $.47^{* * * *}$ & -.06 & $.35^{* * *}$ & $.17^{* *}$ & $.08^{*}$ & $.19^{* * *}$ & $.23^{* * *}$ & $.32^{* * * *}$ & $-.23^{* * *}$ & $-.28^{* * * *}$ & $-.24^{* * * *}$ & $-.27^{* *}$ & $-.30^{* * * *}$ & $-.27^{* * * *}$ & $.48^{* * *}$ & $.15^{* *}$ \\
\hline TRS & $.08^{*}$ & $.11^{* *}$ & 1.00 & $\begin{array}{l}-.01 \\
\end{array}$ & .05 & $.09^{*}$ & $.13^{* *}$ & -.06 & -.05 & $.16^{* *}$ & $-.12^{* *}$ & $-.10^{*}$ & $.16^{* * * *}$ & $.19^{* * *}$ & $.18^{* * *}$ & $.21^{* * * *}$ & $.19^{* *}$ & $-.10^{*}$ & -.07 & $.19^{* *}$ \\
\hline CEOA & .03 & -.07 & -.02 & 1.00 & $.14^{* * *}$ & .03 & .04 & $.09^{*}$ & -.03 & -.07 & $.14^{* * *}$ & .07 & -.06 & -.07 & -.02 & -.04 & -.07 & -.02 & -.01 & -.02 \\
\hline CEOP & $.36^{* * * 4}$ & $.42^{* * *}$ & .06 & $.12^{* *}$ & 1.00 & $.16^{* *}$ & $.47^{* * * *}$ & $.20^{* * *}$ & $.18^{* *}$ & $.20^{* * * *}$ & $.16^{* *}$ & $.11^{* *}$ & $-.15^{* * *}$ & $-.20^{* * * * *}$ & $-.11^{* *}$ & $-.16^{*}$ & $-.19^{* * *}$ & .06 & -.05 & -.04 \\
\hline CEOO & -.02 & -.04 & .08 & .07 & $.19^{* * *}$ & 1.00 & -.02 & $.12^{* *}$ & -.05 & $.36^{* * *}$ & $.25^{* * *}$ & $.08^{*}$ & $.10^{*}$ & $-.12^{* *}$ & -.03 & -.07 & -.06 & -.03 & $-.08^{*}$ & -.00 \\
\hline CEOR & $.30^{* * * *}$ & $.46^{* * * *}$ & $.12^{* *}$ & $.09^{*}$ & $.20^{* * * *}$ & -.05 & 1.00 & $.14^{* *}$ & -.06 & -.05 & -.06 & $.11^{* * *}$ & .05 & $.11^{* *}$ & -.02 & -.04 & -.05 & .07 & .02 & -.00 \\
\hline CEOT & $.08^{*}$ & $.13^{* *}$ & -.05 & .07 & $.15^{* * *}$ & $.10^{*}$ & $.12^{* *}$ & 1.00 & $.10^{*}$ & $.18^{* *}$ & $.09^{*}$ & $.14^{* * *}$ & $-.08^{*}$ & $-.15^{* * *}$ & $-.11^{* * *}$ & $-.15^{* *}$ & $-.19^{* *}$ & -.05 & -.07 & .05 \\
\hline CEOD & -.05 & $.11^{* *}$ & -.07 & -.05 & $.20^{* * *}$ & -.07 & -.05 & $.12^{* *}$ & 1.00 & $.22^{* * * *}$ & $.18^{* *}$ & $-.09^{*}$ & $-.09^{*}$ & $-.13^{* * * *}$ & -.02 & -.04 & -.06 & -.03 & -.03 & .02 \\
\hline FCEO & $.09^{*}$ & $.17^{* *}$ & $.14^{* *}$ & -.03 & $.18^{* * *}$ & $.34^{* * * *}$ & -.07 & $.15^{* *}$ & $.19^{* *}$ & 1.00 & $.21^{* * * *}$ & $.08^{*}$ & .06 & $-.15^{* *}$ & -.03 & -.07 & -.05 & $-.08^{*}$ & -.02 & .00 \\
\hline$B O W$ & $.14^{* * *}$ & $.18^{* *}$ & -.07 & $.12^{* *}$ & $.13^{* *}$ & $.22^{* * * *}$ & -.04 & .07 & $.16^{* *}$ & $.19^{* * *}$ & 1.00 & $-.10^{*}$ & $-.09^{*}$ & $-.10^{*}$ & -.07 & -.03 & -.06 & .06 & $-.09^{*}$ & .00 \\
\hline$B S I Z$ & $.23^{* * * *}$ & $29^{* * * *}$ & -.06 & .04 & $.09^{*}$ & $.20^{* * * *}$ & $.09^{*}$ & $.12^{* *}$ & -.06 & .04 & $-.08^{*}$ & 1.00 & $-.08^{*}$ & $-.09^{*}$ & $.18^{* * * *}$ & $.16^{* *}$ & $.14^{* * *}$ & $.17^{* * *}$ & $.30^{* * *}$ & .00 \\
\hline$D O W$ & $-.13^{* *}$ & $-.19^{* *}$ & $.14^{* *}$ & $\begin{array}{l}.03 \\
\end{array}$ & $-.12^{* *}$ & .07 & .02 & -.06 & -.05 & .03 & -.07 & -.05 & 1.00 & -.07 & -.06 & -.03 & -.05 & -.05 & -.02 & .02 \\
\hline IOW & $-.19^{* *}$ & $-.23^{* * *}$ & $.15^{* *}$ & -.05 & $-.16^{* *}$ & $-.10^{*}$ & $.08^{*}$ & $-.12^{* *}$ & $-.10^{*}$ & $-.11^{* *}$ & $-.08^{*}$ & -.06 & -.04 & 1.00 & $18^{* * * *}$ & $.16^{* *}$ & $.17^{* *}$ & .03 & $.13^{* *}$ & -.04 \\
\hline $\mathrm{NCO}$ & $-.15^{* *}$ & $-.19^{* *}$ & $.10^{*}$ & -.04 & $-.08^{*}$ & .00 & .05 & $-.10^{*}$ & $\begin{array}{l}-.03 \\
\end{array}$ & $\begin{array}{l}-.02 \\
\end{array}$ & -.07 & $.11^{* *}$ & -.05 & $.13^{* *}$ & 1.00 & $.30^{* * *}$ & $.38^{* * * *}$ & -.07 & $.16^{*}$ & -.03 \\
\hline INEDs & $-.13^{* *}$ & $-.17^{* *}$ & $.08^{*}$ & -.06 & $-.12^{* *}$ & .02 & .07 & $-.14^{* *}$ & -.05 & -.03 & -.05 & $.13^{* *}$ & -.03 & $-16^{* *}$ & $32^{* * *}$ & 1.00 & $.26^{* *}$ & -.04 & $.14^{* *}$ & $.10^{*}$ \\
\hline$R C O$ & $-.24^{* * * *}$ & $-.28^{* * * *}$ & $.13^{* *}$ & -.03 & $-.15^{* *}$ & .04 & .04 & $-.17^{* *}$ & -.07 & -.05 & -.04 & $.15^{* *}$ & -.05 & $.14^{* * *}$ & $.35^{* * * *}$ & $.20^{* * * *}$ & 1.00 & -.06 & $.19^{* *}$ & $.08^{*}$ \\
\hline$L E V$ & $-.22^{* *}$ & $-.24^{* * *}$ & -.07 & -.05 & -.07 & -.06 & $.09^{*}$ & -.07 & -.06 & $-.10^{*}$ & $.08^{*}$ & $.22^{* * * *}$ & -.07 & .05 & -.06 & -.07 & -.03 & 1.00 & $.34^{* * * *}$ & .03 \\
\hline$F S Z$ & $.42^{* * * *}$ & $.46^{* * * *}$ & -.05 & -.02 & .05 & $-.10^{*}$ & .04 & -.05 & -.07 & -.05 & $-.11^{* * *}$ & $.33^{* * *}$ & -.05 & $.16^{* *}$ & $.18^{* * *}$ & $.20^{* * * *}$ & $.14^{* * *}$ & $.25^{* * * *}$ & 1.00 & -.05 \\
\hline SAGR & $.08^{*}$ & $.12^{* *}$ & $.16^{* *}$ & -.05 & -.07 & .03 & -.03 & .05 & .06 & .00 & .01 & .05 & -.07 & -.02 & $-.09^{*}$ & $.11^{* *}$ & $.13^{* *}$ & .07 & -.03 & 1.00 \\
\hline
\end{tabular}

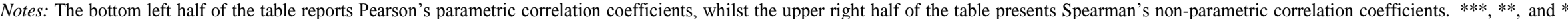
indicate correlation is significant at the 1\%,5\% and 10\% level, respectively (two-tailed tests). Variables are defined as follows: total pay of all executive directors (TEPAY), total CEO pay (CEPAY), total return for shareholers (TRS), CEO age $(C E O A)$, CEO pOwer $(C E O P)$, CEO OWnership (CEOO), CEO reputation $(C E O R)$, CEO tenure $(C E O T)$, CEO duality $(C E O D)$, founding CEO (FCEO), block OWnership (BOW

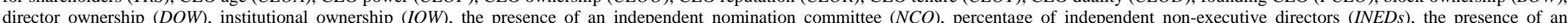
independent remuneration committee $(R C O)$, leverage $(L V)$, firm size $(F S Z)$ and sales growth (SAGR). Table 3 contains full definitions of all the variables employed. 
Table 6. The effect of corporate performance on executive pay

Dependent variable

\begin{tabular}{|c|c|c|c|c|c|c|}
\hline \multirow[b]{2}{*}{$\begin{array}{l}\text { Independent variable } \\
\text { Model }\end{array}$} & \multicolumn{3}{|c|}{ All executive directors' pay } & \multicolumn{3}{|c|}{ CEO pay } \\
\hline & $\begin{array}{l}\Delta \text { Cash } \\
\text { (I) }\end{array}$ & $\begin{array}{l}\Delta \text { Non-cash } \\
\text { (II) }\end{array}$ & $\begin{array}{l}\Delta \text { Total } \\
\text { (III) }\end{array}$ & $\begin{array}{l}\Delta \text { Cash } \\
\text { (IV) }\end{array}$ & $\begin{array}{l}\Delta \text { Non-cash } \\
(\mathrm{V})\end{array}$ & $\begin{array}{l}\Delta \text { Total } \\
\text { (VI) }\end{array}$ \\
\hline \multicolumn{7}{|c|}{ Corporate Performance variable: } \\
\hline$\Delta T R S_{t-1}$ & $\begin{array}{l}0.029^{* *} \\
(.000)\end{array}$ & $\begin{array}{l}0.051^{* * * *} \\
(.000)\end{array}$ & $\begin{array}{l}0.063^{* * *} \\
(.000)\end{array}$ & $\begin{array}{l}0.048^{* * * *} \\
(.000)\end{array}$ & $\begin{array}{l}0.069^{* * * *} \\
(.000)\end{array}$ & $\begin{array}{l}0.095^{* * * *} \\
(.000)\end{array}$ \\
\hline \multicolumn{7}{|l|}{ Control variables: } \\
\hline$\Delta B G 4_{t-1}$ & $\begin{array}{l}0.147^{* *} \\
(.034)\end{array}$ & $\begin{array}{l}0.140^{* *} \\
(.042)\end{array}$ & $\begin{array}{l}0.175^{* * * *} \\
(.000)\end{array}$ & $\begin{array}{l}0.170^{* *} \\
(.000)\end{array}$ & $\begin{array}{l}0.180^{* * * *} \\
(.000)\end{array}$ & $\begin{array}{l}0.204^{* * *} \\
(.000)\end{array}$ \\
\hline$\triangle C P E X_{t-1}$ & $\begin{array}{l}-0.030^{* * *} \\
(.044)\end{array}$ & $\begin{array}{l}-0.067^{* * * *} \\
(.010)\end{array}$ & $\begin{array}{l}-0.098^{* * * *} \\
(.000)\end{array}$ & $\begin{array}{l}-0.062^{* * *} \\
(.020)\end{array}$ & $\begin{array}{l}-0.103^{\text {***** }} \\
(.000)\end{array}$ & $\begin{array}{l}-0.116^{\text {**** }} \\
(.000)\end{array}$ \\
\hline$\Delta C G C O_{t-1}$ & $\begin{array}{l}-0.186^{* * * *} \\
(.000)\end{array}$ & $\begin{array}{l}-0.177^{* * * *} \\
(.000)\end{array}$ & $\begin{array}{l}-0.202^{* * * *} \\
(.000)\end{array}$ & $\begin{array}{l}-0.197^{* * * *} \\
(.000)\end{array}$ & $\begin{array}{l}-0.205^{* * * * *} \\
(.000)\end{array}$ & $\begin{array}{l}-0.210^{* * * *} \\
(.000)\end{array}$ \\
\hline$\Delta C L I S T_{t-1}$ & $\begin{array}{l}0.123^{* *} \\
(.029)\end{array}$ & $\begin{array}{l}0.170^{* * * *} \\
(.010)\end{array}$ & $\begin{array}{l}0.182^{* * * *} \\
(.000)\end{array}$ & $\begin{array}{l}0.140^{* * *} \\
(.019)\end{array}$ & $\begin{array}{l}0.181^{\text {***** }} \\
(.000)\end{array}$ & $\begin{array}{l}0.195^{* * * *} \\
(.000)\end{array}$ \\
\hline$\Delta D V_{t-1}$ & $\begin{array}{l}-0.120^{* * *} \\
(.050)\end{array}$ & $\begin{array}{l}-0.171^{* *} \\
(.020)\end{array}$ & $\begin{array}{l}-0.185^{* * * *} \\
(.009)\end{array}$ & $\begin{array}{l}-0.130^{* *} \\
(.036)\end{array}$ & $\begin{array}{l}-0.194^{* * * *} \\
(.000)\end{array}$ & $\begin{array}{l}-0.211^{* * * *} \\
(.000)\end{array}$ \\
\hline$\Delta L V_{t-1}$ & $\begin{array}{l}-0.035^{* *} \\
(.046)\end{array}$ & $\begin{array}{l}-0.040^{* * *} \\
(.032)\end{array}$ & $\begin{array}{l}-0.055^{* *} \\
(.016)\end{array}$ & $\begin{array}{l}-0.065^{* * * *} \\
(.009)\end{array}$ & $\begin{array}{l}-0.086^{* * * *} \\
(.000)\end{array}$ & $\begin{array}{l}-0.104^{* * * *} \\
(.000)\end{array}$ \\
\hline$\Delta F S Z_{t-1}$ & $\begin{array}{l}0.210^{* * * *} \\
(.000)\end{array}$ & $\begin{array}{l}0.238^{* * * *} \\
(.000)\end{array}$ & $\begin{array}{l}0.262^{* * * *} \\
(.000)\end{array}$ & $\begin{array}{l}0.225^{* * * *} \\
(.000)\end{array}$ & $\begin{array}{l}0.246^{* * * *} \\
(.000)\end{array}$ & $\begin{array}{l}0.289^{* * * *} \\
(.000)\end{array}$ \\
\hline$\Delta S A G R_{t-1}$ & $\begin{array}{l}0.106^{* * * *} \\
(.000)\end{array}$ & $\begin{array}{l}0.120^{* * * *} \\
(.000)\end{array}$ & $\begin{array}{l}0.145^{\text {**** }} \\
(.000)\end{array}$ & $\begin{array}{l}0.134^{* * * *} \\
(.000)\end{array}$ & $\begin{array}{l}0.156^{* * * *} \\
(.000)\end{array}$ & $\begin{array}{l}0.172^{\text {***** }} \\
(.000)\end{array}$ \\
\hline$I N D$ & Included & Included & Included & Included & Included & Included \\
\hline$Y E D$ & Included & Included & Included & Included & Included & Included \\
\hline Constant & $\begin{array}{l}1.674^{* * * *} \\
(.000)\end{array}$ & $\begin{array}{l}1.695^{* * * *} \\
(.000)\end{array}$ & $\begin{array}{l}1.686^{* * * *} \\
(.000)\end{array}$ & $\begin{array}{l}1.896^{* * *} \\
(.000)\end{array}$ & $\begin{array}{l}1.952^{* * * *} \\
(.000)\end{array}$ & $\begin{array}{l}1.932^{* * * *} \\
(.000)\end{array}$ \\
\hline$F$-value & $6.254^{* * * *}$ & $6.306^{* * * *}$ & $6.279^{* * * *}$ & $6.556^{* * * *}$ & $6.965^{* * * *}$ & $6.784^{* * * *}$ \\
\hline Adjusted $R^{2}$ & 0.372 & 0.380 & 0.388 & 0.390 & 0.402 & 0.412 \\
\hline$N$ & 1,521 & 1,521 & 1,521 & 1,521 & 1,521 & 1,521 \\
\hline
\end{tabular}

Notes: The table presents a median regression of changes $(\Delta)$ in cash, non-cash and total pay of all executive directors and the CEO, respectively, on changes in shareholder wealth (corporate performance) and the control variables. $P$-values are in parentheses. Following Peterson (2009), the coefficients are estimated by using the robust Clustered Standard Errors technique. ***, **, and * denote significance at the $1 \%, 5 \%$ and $10 \%$ levels, respectively. The other variables are defined as follows: changes $(\Delta)$ in total return for shareholders $(\triangle T R S)$, audit firm size $(\triangle B G 4)$, capital expenditure $(\triangle C P E X)$, the presence of a CG committee $(\triangle C G C O)$, crosslisting $(\triangle C L I S T)$, dividend payment status $(\triangle D V)$, leverage $(\triangle L V)$, firm size $(\triangle F S Z)$, sales growth $(\triangle S A G R)$, year $(Y E D)$ and industry $(I N D)$ dummies. Table 3 fully defines all the variables used. 
Table 7: Statistical comparisons of the differences in estimated PPS between CEOs and executive directors

\begin{tabular}{|c|c|c|c|}
\hline Variable & $\begin{array}{l}\text { PPS coefficient for } \\
\text { executives }\end{array}$ & $\begin{array}{l}\text { PPS coefficient for } \\
\text { CEOs }\end{array}$ & $\begin{array}{l}\text { T-test of PPS difference: } \\
\text { (CEOs - Executives) }\end{array}$ \\
\hline \multicolumn{4}{|c|}{ Panel A: Estimated PPS coefficients from Table 6} \\
\hline Cash (TRS) & 0.029 & 0.048 & $0.019^{*}$ \\
\hline Non-Cash (TRS) & 0.051 & 0.069 & $0.018^{*}$ \\
\hline Total (TRS) & 0.063 & 0.095 & $0.032^{* * * *}$ \\
\hline \multicolumn{4}{|c|}{ Panel B: Estimated PPS coefficients from Table 8} \\
\hline $\mathrm{Q}$ & 0.152 & 0.175 & $0.023^{* * *}$ \\
\hline OROA & 0.165 & 0.186 & $0.021^{* * *}$ \\
\hline TSR & 0.157 & 0.180 & $0.023^{* *}$ \\
\hline \multicolumn{4}{|c|}{ Panel C: Estimated PPS coefficients from Table 9} \\
\hline Q & 0.136 & 0.153 & $0.017^{*}$ \\
\hline OROA & 0.147 & 0.158 & $0.011^{*}$ \\
\hline TSR & 0.142 & 0.155 & $0.013^{*}$ \\
\hline \multicolumn{4}{|c|}{ Panel D: Estimated PPS coefficients from Table 10} \\
\hline PRE_TRS (Step 1) & 0.140 & 0.144 & 0.004 \\
\hline PRE_TRS (Step 2) & 0.165 & 0.178 & $0.013^{* *}$ \\
\hline \multicolumn{4}{|c|}{ Panel E: Estimated PPS coefficients from Table 11} \\
\hline PRE_TRS (Step 1) & 0.130 & 0.141 & $0.011^{*}$ \\
\hline PRE_TRS (Step 2) & 0.149 & 0.169 & $0.020^{* * *}$ \\
\hline \multicolumn{4}{|c|}{ Panel F: Estimated PPS coefficients from Table 12} \\
\hline PRE_Q & 0.160 & 0.182 & $0.022^{* * *}$ \\
\hline PRE_OROA & 0.171 & 0.196 & $0.025^{* *}$ \\
\hline PRE_TRS & 0.165 & 0.194 & $0.029^{* * * *}$ \\
\hline \multicolumn{4}{|c|}{ Panel G: Estimated PPS coefficients from Table 13} \\
\hline PRE_Q & 0.145 & 0.164 & $0.019^{*}$ \\
\hline PRE_OROA & 0.156 & 0.169 & $0.013^{*}$ \\
\hline PRE_TRS & 0.153 & 0.167 & $0.014^{*}$ \\
\hline
\end{tabular}

Notes: The table contains PPS coefficients estimated in Tables 6, and 8 to 13 for CEOs and all executive directors along with their differences (CEOs coefficients minus coefficients of all executive directors). ${ }^{* * *},{ }^{* *}$, and ${ }^{*}$ denote that the difference between the estimated PPS for CEOs and all executive directors is significant at the $1 \%, 5 \%$, and $10 \%$ level, respectively. 
Table 8. The moderating effect of CEO power on the pay-for-performance relationship

\begin{tabular}{|c|c|c|c|c|c|c|}
\hline \multirow[b]{3}{*}{$\begin{array}{l}\text { Independent variable } \\
\text { Model }\end{array}$} & \multicolumn{6}{|c|}{ Dependent variable } \\
\hline & \multicolumn{3}{|c|}{$\Delta$ All executive directors' pay } & \multicolumn{3}{|c|}{$\triangle \mathrm{CEO}$ pay } \\
\hline & $\begin{array}{c}\Delta \text { TEPAY } \\
(\mathrm{I})\end{array}$ & $\begin{array}{l}\Delta \text { TEPAY } \\
\text { (II) }\end{array}$ & $\begin{array}{l}\triangle \mathrm{TEPAY} \\
\text { (III) }\end{array}$ & $\begin{array}{c}\triangle \mathrm{CEPAY} \\
(\mathrm{IV})\end{array}$ & $\begin{array}{l}\triangle \mathrm{CEPAY} \\
(\mathrm{V})\end{array}$ & $\begin{array}{c}\Delta \mathrm{CEPAY} \\
(\mathrm{VI})\end{array}$ \\
\hline \multicolumn{7}{|c|}{ Corporate performance variable: } \\
\hline$\Delta Q_{t-1}$ & $\begin{array}{l}0.152^{* * *} \\
(.000)\end{array}$ & $\begin{array}{l}- \\
-\end{array}$ & - & $\begin{array}{l}0.175^{\text {***** }} \\
(.000)\end{array}$ & - & - \\
\hline$\triangle O R O A_{t-1}$ & - & $\begin{array}{l}0.165^{* * *} \\
(.000)\end{array}$ & - & - & $\begin{array}{l}0.186^{* * *} \\
(.000)\end{array}$ & $\begin{array}{l}- \\
-\end{array}$ \\
\hline$\Delta T R S_{t-1}$ & - & - & $\begin{array}{l}0.157^{* *} \\
(.000)\end{array}$ & - & $\begin{array}{l}- \\
-\end{array}$ & $\begin{array}{l}0.180^{* * *} \\
(.000)\end{array}$ \\
\hline \multicolumn{7}{|l|}{ CEO power variables: } \\
\hline$\triangle C E O A_{t-1}$ & $\begin{array}{l}-0.012 \\
(.345)\end{array}$ & $\begin{array}{r}-0.018 \\
(.320)\end{array}$ & $\begin{array}{r}-0.015 \\
(.330)\end{array}$ & $\begin{array}{r}-0.017 \\
(.323)\end{array}$ & $\begin{array}{r}-0.025 \\
(.310)\end{array}$ & $\begin{array}{r}-0.020 \\
(.316)\end{array}$ \\
\hline$\triangle C E O D_{t-1}$ & $\begin{array}{l}-0.005 \\
(.594)\end{array}$ & $\begin{array}{l}-0.008 \\
(.573)\end{array}$ & $\begin{array}{r}-0.006 \\
(.587)\end{array}$ & $\begin{array}{r}-0.010 \\
(.562)\end{array}$ & $\begin{array}{r}-0.016 \\
(.545)\end{array}$ & $\begin{array}{r}-0.014 \\
(.552)\end{array}$ \\
\hline$\Delta C E O O_{t-1}$ & $\begin{array}{l}0.203^{* * *} \\
(.000)\end{array}$ & $\begin{array}{l}0.209^{* * * *} \\
(.000)\end{array}$ & $\begin{array}{l}0.205^{* * * *} \\
(.000)\end{array}$ & $\begin{array}{l}0.216^{* * *} \\
(.000)\end{array}$ & $\begin{array}{l}0.227^{* * * *} \\
(.000)\end{array}$ & $\begin{array}{l}0.220^{* * * *} \\
(.000)\end{array}$ \\
\hline$\triangle C E O P_{t-1}$ & $\begin{array}{l}-0.133^{* * *} \\
(.000)\end{array}$ & $\begin{array}{l}-0.139^{* * *} \\
(.000)\end{array}$ & $\begin{array}{l}-0.136^{* * * *} \\
(.000)\end{array}$ & $\begin{array}{c}-0.140^{* * * *} \\
(.000)\end{array}$ & $\begin{array}{c}-0.147^{* * * *} \\
(.000)\end{array}$ & $\begin{array}{c}-0.143^{* * * *} \\
(.000)\end{array}$ \\
\hline$\triangle C E O R_{t-1}$ & $\begin{array}{l}0.162^{* * *} \\
(.000)\end{array}$ & $\begin{array}{l}0.167^{* * *} \\
(.000)\end{array}$ & $\begin{array}{l}0.165^{* * * *} \\
(.000)\end{array}$ & $\begin{array}{l}0.170^{* * * *} \\
(.000)\end{array}$ & $\begin{array}{l}0.177^{* * * *} \\
(.000)\end{array}$ & $\begin{array}{l}0.174^{* * * *} \\
(.000)\end{array}$ \\
\hline$\Delta C E O T_{t-1}$ & $\begin{array}{l}-0.102^{* *} \\
(.038)\end{array}$ & $\begin{array}{l}-0.107^{* *} \\
(.032)\end{array}$ & $\begin{array}{c}-0.105^{* *} \\
(.036)\end{array}$ & $\begin{array}{l}-0.109^{* *} \\
(.030)\end{array}$ & $\begin{array}{l}-0.115^{* *} \\
(.024)\end{array}$ & $\begin{array}{l}-0.112^{* *} \\
(.028)\end{array}$ \\
\hline$\Delta F C E O_{t-1}$ & $\begin{array}{l}0.053^{*} \\
(.064)\end{array}$ & $\begin{array}{l}0.060^{*} \\
(.058)\end{array}$ & $\begin{array}{l}0.057^{*} \\
(.060)\end{array}$ & $\begin{array}{l}0.063^{*} \\
(.054)\end{array}$ & $\begin{array}{l}0.067^{* *} \\
(.048)\end{array}$ & $\begin{array}{l}0.065^{\text {** }} \\
(.050)\end{array}$ \\
\hline Interaction variables. & & & & & & \\
\hline$\Delta P^{*} C E O A_{t-1}$ & $\begin{array}{r}-0.003 \\
(.372)\end{array}$ & $\begin{array}{r}-0.008 \\
(.364)\end{array}$ & $\begin{array}{r}-0.005 \\
(.368)\end{array}$ & $\begin{array}{r}-0.010 \\
(.349)\end{array}$ & $\begin{array}{r}-0.016 \\
(.335)\end{array}$ & $\begin{array}{r}-0.013 \\
(.340)\end{array}$ \\
\hline$\Delta P^{*} C E O D_{t-1}$ & $\begin{array}{l}-0.001 \\
(.630)\end{array}$ & $\begin{array}{r}-0.004 \\
(.610)\end{array}$ & $\begin{array}{r}-0.002 \\
(.625)\end{array}$ & $\begin{array}{r}-0.005 \\
(.596)\end{array}$ & $\begin{array}{r}-0.010 \\
(.570)\end{array}$ & $\begin{array}{r}-0.007 \\
(.585)\end{array}$ \\
\hline$\Delta P^{*} C E O O_{t-1}$ & $\begin{array}{l}0.182^{* * * *} \\
(.000)\end{array}$ & $\begin{array}{l}0.188^{* * *} \\
(.000)\end{array}$ & $\begin{array}{l}0.184^{* * * *} \\
(.000)\end{array}$ & $\begin{array}{l}0.197^{* * *} \\
(.000)\end{array}$ & $\begin{array}{l}0.210^{* * * *} \\
(.000)\end{array}$ & $\begin{array}{l}0.206^{\text {***** }} \\
(.000)\end{array}$ \\
\hline$\Delta P^{*} C E O P_{t-1}$ & $\begin{array}{c}-0.120^{* * * *} \\
(.000)\end{array}$ & $\begin{array}{c}-0.127^{* * * *} \\
(.000)\end{array}$ & $\begin{array}{c}-0.123^{* * * *} \\
(.000)\end{array}$ & $\begin{array}{c}-0.129^{* * * *} \\
(.000)\end{array}$ & $\begin{array}{c}-0.136^{* * * *} \\
(.000)\end{array}$ & $\begin{array}{c}-0.133^{* * * *} \\
(.000)\end{array}$ \\
\hline$\Delta P^{*} C E O R_{t-1}$ & $\begin{array}{l}0.143^{* * * *} \\
(.000)\end{array}$ & $\begin{array}{l}0.148^{\text {**** }} \\
(.000)\end{array}$ & $\begin{array}{l}0.145^{* * * *} \\
(.000)\end{array}$ & $\begin{array}{l}0.153^{\text {**** }} \\
(.000)\end{array}$ & $\begin{array}{l}0.159^{* * * *} \\
(.000)\end{array}$ & $\begin{array}{l}0.156^{* * * *} \\
(.000)\end{array}$ \\
\hline$\Delta P^{*} C E O T_{t-1}$ & $\begin{array}{l}-0.078^{*} \\
(.052)\end{array}$ & $\begin{array}{c}-0.085^{* *} \\
(.046)\end{array}$ & $\begin{array}{c}-0.082^{* * *} \\
(.049)\end{array}$ & $\begin{array}{c}-0.090^{* *} \\
(.040)\end{array}$ & $\begin{array}{c}-0.097^{* *} \\
(.035)\end{array}$ & $\begin{array}{c}-0.093^{* *} \\
(.037)\end{array}$ \\
\hline$\Delta P^{*} F C E O_{t-1}$ & $\begin{array}{l}0.044^{*} \\
(.077)\end{array}$ & $\begin{array}{l}0.048^{*} \\
(.072)\end{array}$ & $\begin{array}{l}0.046^{*} \\
(.074)\end{array}$ & $\begin{array}{l}0.053^{*} \\
(.068)\end{array}$ & $\begin{array}{l}0.059^{*} \\
(.063)\end{array}$ & $\begin{array}{l}0.056^{*} \\
(.065)\end{array}$ \\
\hline$\triangle C O N T R O L S$ & Included & Included & Included & Included & Included & Included \\
\hline Constant & $\begin{array}{l}2.165^{* * * *} \\
(.000)\end{array}$ & $\begin{array}{l}2.187^{* * * *} \\
(.000)\end{array}$ & $\begin{array}{l}2.174^{* * * *} \\
(.000)\end{array}$ & $\begin{array}{l}2.295^{* * * *} \\
(.000)\end{array}$ & $\begin{array}{l}2.467^{* * *} \\
(.000)\end{array}$ & $\begin{array}{l}2.325^{\text {**** }} \\
(.000)\end{array}$ \\
\hline$F$-value & $7.176^{* * *}$ & $7.341^{* * *}$ & $7.269^{* * *}$ & $7.508^{* * * *}$ & $7.757^{* * * *}$ & $7.652^{* * * *}$ \\
\hline Adjusted $R^{2}$ & 0.442 & 0.448 & 0.443 & 0.452 & 0.469 & 0.464 \\
\hline$N$ & 1,521 & 1,521 & 1,521 & 1,521 & 1,521 & 1,521 \\
\hline
\end{tabular}


in Table 6 are included in each model, but for brevity not reported and available upon request. Table 3 fully defines all the variables used.

Table 9. The moderating effect of governance structure on the pay-for-performance relationship

\begin{tabular}{|c|c|c|c|c|c|c|}
\hline \multirow[b]{3}{*}{$\begin{array}{l}\text { Independent variable } \\
\text { Model }\end{array}$} & \multicolumn{6}{|c|}{ Dependent variable } \\
\hline & \multicolumn{3}{|c|}{$\Delta$ All executive directors' pay } & \multicolumn{3}{|c|}{$\triangle \mathrm{CEO}$ pay } \\
\hline & $\begin{array}{l}\Delta \text { TEPAY } \\
\text { (I) }\end{array}$ & $\begin{array}{l}\triangle \mathrm{TEPAY} \\
\text { (II) }\end{array}$ & $\begin{array}{l}\triangle \mathrm{TEPAY} \\
\text { (III) }\end{array}$ & $\begin{array}{c}\Delta \mathrm{CEPAY} \\
\text { (IV) }\end{array}$ & $\begin{array}{c}\Delta \mathrm{CEPAY} \\
(\mathrm{V})\end{array}$ & $\begin{array}{c}\triangle \mathrm{CEPAY} \\
(\mathrm{VI})\end{array}$ \\
\hline \multicolumn{7}{|c|}{ Corporate performance variables: } \\
\hline$\Delta Q_{t-1}$ & $\begin{array}{l}0.136^{* * * *} \\
(.000)\end{array}$ & - & - & $\begin{array}{l}0.153^{* * *} \\
(.000)\end{array}$ & $\begin{array}{l}- \\
-\end{array}$ & - \\
\hline$\Delta O R O A_{t-1}$ & $\begin{array}{l}- \\
-\end{array}$ & $\begin{array}{l}0.147^{* * *} \\
(.000)\end{array}$ & - & - & $\begin{array}{l}0.158^{* * * *} \\
(.000)\end{array}$ & - \\
\hline$\Delta T R S_{t-1}$ & - & $\begin{array}{l}- \\
-\end{array}$ & $\begin{array}{l}0.142^{* *} \\
(.000)\end{array}$ & - & - & $\begin{array}{l}0.155^{* * *} \\
(.000)\end{array}$ \\
\hline \multicolumn{7}{|c|}{$\begin{array}{l}\text { Corporate governance structure: } \\
\text { Ownership structure variables: }\end{array}$} \\
\hline$\Delta B O W N_{t-1}$ & $\begin{array}{c}-0.008 \\
(.520)\end{array}$ & $\begin{array}{r}-0.014 \\
(.512)\end{array}$ & $\begin{array}{r}-0.011 \\
(.515)\end{array}$ & $\begin{array}{r}-0.013 \\
(.510)\end{array}$ & $\begin{array}{r}-0.018 \\
(.492)\end{array}$ & $\begin{array}{r}-0.016 \\
(.504)\end{array}$ \\
\hline$\Delta D O W N_{t-I}$ & $\begin{array}{l}0.123^{* * *} \\
(.000)\end{array}$ & $\begin{array}{l}0.130^{* * *} \\
(.000)\end{array}$ & $\begin{array}{l}0.127^{* * * *} \\
(.000)\end{array}$ & $\begin{array}{l}0.128^{* * *} \\
(.000)\end{array}$ & $\begin{array}{l}0.136^{* * * *} \\
(.000)\end{array}$ & $\begin{array}{l}0.132^{* * * *} \\
(.000)\end{array}$ \\
\hline$\Delta I O W N_{t-1}$ & $\begin{array}{l}0.072^{*} \\
(.064)\end{array}$ & $\begin{array}{l}0.079^{*} \\
(.058)\end{array}$ & $\begin{array}{l}0.076^{*} \\
(.060)\end{array}$ & $\begin{array}{l}0.082^{*} \\
(.054)\end{array}$ & $\begin{array}{l}0.090^{* *} \\
(.048)\end{array}$ & $\begin{array}{l}0.087^{* *} \\
(.050)\end{array}$ \\
\hline \multicolumn{7}{|c|}{ Board structure variables: } \\
\hline$\Delta B S I Z_{t-1}$ & $\begin{array}{l}-0.243^{* * *} \\
(.000)\end{array}$ & $\begin{array}{l}-0.255^{* * *} \\
(.000)\end{array}$ & $\begin{array}{l}-0.248^{* * * *} \\
(.000)\end{array}$ & $\begin{array}{l}-0.260^{* * *} \\
(.000)\end{array}$ & $\begin{array}{l}-0.267^{* * * *} \\
(.000)\end{array}$ & $\begin{array}{l}-0.264^{* * * *} \\
(.000)\end{array}$ \\
\hline$\Delta F B M_{t-1}$ & $\begin{array}{l}0.019 \\
(.373)\end{array}$ & $\begin{array}{l}0.028 \\
(.362)\end{array}$ & $\begin{array}{l}0.025 \\
(.367)\end{array}$ & $\begin{array}{l}0.029 \\
(.358)\end{array}$ & $\begin{array}{l}0.037 \\
(.349)\end{array}$ & $\begin{array}{l}0.033 \\
(.352)\end{array}$ \\
\hline$\Delta N C O_{t-1}$ & $\begin{array}{l}0.120^{* * *} \\
(.000)\end{array}$ & $\begin{array}{l}0.128^{* * * *} \\
(.000)\end{array}$ & $\begin{array}{l}0.124^{* * * *} \\
(.000)\end{array}$ & $\begin{array}{l}0.131^{* * * *} \\
(.000)\end{array}$ & $\begin{array}{l}0.139^{* * * *} \\
(.000)\end{array}$ & $\begin{array}{l}0.135^{* * * *} \\
(.000)\end{array}$ \\
\hline$\Delta I N E D s_{t-1}$ & $\begin{array}{l}-0.006 \\
(.593)\end{array}$ & $\begin{array}{l}-0.009 \\
(.582)\end{array}$ & $\begin{array}{l}-0.007 \\
(.586)\end{array}$ & $\begin{array}{l}-0.008 \\
(.584)\end{array}$ & $\begin{array}{l}-0.015 \\
(.577)\end{array}$ & $\begin{array}{l}-0.011 \\
(.580)\end{array}$ \\
\hline$\Delta R C O_{t-1}$ & $\begin{array}{l}0.130^{* * * *} \\
(.000)\end{array}$ & $\begin{array}{l}0.137^{* * * *} \\
(.000)\end{array}$ & $\begin{array}{l}0.133^{* * * *} \\
(.000)\end{array}$ & $\begin{array}{l}0.135^{* * * *} \\
(.000)\end{array}$ & $\begin{array}{l}0.140^{* * * *} \\
(.000)\end{array}$ & $\begin{array}{l}0.137^{\text {**** }} \\
(.000)\end{array}$ \\
\hline \multicolumn{7}{|l|}{ Interaction variables: } \\
\hline$\Delta P^{*} B O W_{t-1}$ & $\begin{array}{r}-0.001 \\
(.575)\end{array}$ & $\begin{array}{r}-0.005 \\
(.562)\end{array}$ & $\begin{array}{r}-0.003 \\
(.569)\end{array}$ & $\begin{array}{r}-0.006 \\
(.545)\end{array}$ & $\begin{array}{r}-0.009 \\
(.536)\end{array}$ & $\begin{array}{r}-0.007 \\
(.540)\end{array}$ \\
\hline$\Delta P^{*} D O W_{t-1}$ & $\begin{array}{l}0.107^{* * *} \\
(.000)\end{array}$ & $\begin{array}{l}0.115^{* * * *} \\
(.000)\end{array}$ & $\begin{array}{l}0.110^{* * * *} \\
(.000)\end{array}$ & $\begin{array}{l}0.117^{* * * *} \\
(.000)\end{array}$ & $\begin{array}{l}0.125^{\text {**** }} \\
(.000)\end{array}$ & $\begin{array}{l}0.120^{* * * *} \\
(.000)\end{array}$ \\
\hline$\Delta P^{*} I O W_{t-1}$ & $\begin{array}{c}0.060^{*} \\
(.089)\end{array}$ & $\begin{array}{l}0.067^{*} \\
(.084)\end{array}$ & $\begin{array}{l}0.064^{*} \\
(.087)\end{array}$ & $\begin{array}{l}0.069^{*} \\
(.081)\end{array}$ & $\begin{array}{l}0.075^{*} \\
(.070)\end{array}$ & $\begin{array}{l}0.073^{*} \\
(.074)\end{array}$ \\
\hline \multicolumn{7}{|c|}{ Board structure variables: } \\
\hline$\Delta P^{*} B S I Z_{t-1}$ & $\begin{array}{c}-0.225^{* * * *} \\
(.000)\end{array}$ & $\begin{array}{c}-0.234^{* * *} \\
(.000)\end{array}$ & $\begin{array}{c}-0.229^{* * * *} \\
(.000)\end{array}$ & $\begin{array}{c}-0.235^{\text {**** }} \\
(.000)\end{array}$ & $\begin{array}{c}-0.243^{* * * *} \\
(.000)\end{array}$ & $\begin{array}{c}-0.240^{* * * *} \\
(.000)\end{array}$ \\
\hline$\Delta P^{*} F B M_{t-1}$ & $\begin{array}{l}0.002 \\
(.439)\end{array}$ & $\begin{array}{l}0.005 \\
(.428)\end{array}$ & $\begin{array}{l}0.003 \\
(.430)\end{array}$ & $\begin{array}{l}0.006 \\
(.425)\end{array}$ & $\begin{array}{l}0.009 \\
(.418)\end{array}$ & $\begin{array}{l}0.007 \\
(.420)\end{array}$ \\
\hline$\Delta P^{*} N C O_{t-1}$ & $\begin{array}{l}0.109^{* * * *} \\
(.000)\end{array}$ & $\begin{array}{l}0.117^{* * *} \\
(.000)\end{array}$ & $\begin{array}{l}0.114^{* * * *} \\
(.000)\end{array}$ & $\begin{array}{l}0.119^{* * * *} \\
(.000)\end{array}$ & $\begin{array}{l}0.126^{* * * *} \\
(.000)\end{array}$ & $\begin{array}{l}0.122^{* * * *} \\
(.000)\end{array}$ \\
\hline$\Delta P * I N E D s_{t-1}$ & $\begin{array}{l}-0.001 \\
(.630)\end{array}$ & $\begin{array}{l}-0.005 \\
(.622)\end{array}$ & $\begin{array}{l}-0.003 \\
(.627)\end{array}$ & $\begin{array}{l}-0.008 \\
(.611)\end{array}$ & $\begin{array}{l}-0.014 \\
(.600)\end{array}$ & $\begin{array}{l}-0.010 \\
(.608)\end{array}$ \\
\hline$\Delta P * R C O_{t-1}$ & $\begin{array}{l}0.118^{* * * *} \\
(.000)\end{array}$ & $\begin{array}{c}-0.125^{* * *} \\
(.000)\end{array}$ & $\begin{array}{c}-0.123^{\text {***** }} \\
(.000)\end{array}$ & $\begin{array}{c}-0.126^{* * * *} \\
(.000)\end{array}$ & $\begin{array}{c}-0.132^{* * * *} \\
(.000)\end{array}$ & $\begin{array}{c}-0.129^{* * * *} \\
(.000)\end{array}$ \\
\hline$\triangle C O N T R O L S$ & Included & Included & Included & Included & Included & Included \\
\hline Constant & $\begin{array}{l}2.365^{* * *} \\
(.000)\end{array}$ & $\begin{array}{l}2.394^{* * * *} \\
(.000)\end{array}$ & $\begin{array}{l}2.375^{\text {**** }} \\
(.000)\end{array}$ & $\begin{array}{l}2.492^{* * * *} \\
(.000)\end{array}$ & $\begin{array}{l}2.637^{\text {**** }} \\
(.000)\end{array}$ & $\begin{array}{l}2.573^{* * *} \\
(.000)\end{array}$ \\
\hline
\end{tabular}




\begin{tabular}{lllllll}
$F$-value & $8.057^{* * * *}$ & $8.169^{* * * *}$ & $8.112^{* * * *}$ & $8.176^{* * * *}$ & $8.207^{* * * * *}$ & $8.194^{* * * *}$ \\
Adjusted $R^{2}$ & 0.453 & 0.462 & 0.458 & 0.465 & 0.474 & 0.469 \\
$N$ & 1,521 & 1,521 & 1,521 & 1,521 & 1,521 & 1,521 \\
\hline
\end{tabular}

Notes: P-values are in parentheses. Following Peterson (2009), the coefficients are estimated by using the robust Clustered Standard

Errors technique. $* * *, * *$, and $*$ denote significance at the $1 \%, 5 \%$ and $10 \%$ levels, respectively. $\Delta$ is the first-difference operator and is applied to the variables as follows: Total executive pay (TEPAY), total CEO pay $(C E P A Y)$, Tobin's $\mathrm{Q}(\triangle Q)$, operating return on assets $(\triangle R O A)$, total return for shareholders $(\triangle T R S)$, block ownership $(\triangle B O W)$, director ownership $(D O W)$, institutional ownership $(\triangle I O W)$, board size $(\triangle B S I Z)$, number of board meetings $(\triangle F B M)$, the presence of an independent nomination committee $(\triangle N C O)$, percentage of independent non-executive directors $(\triangle I N E D s)$ and the presence of an independent remuneration committee $(\triangle R C O)$. The next set of eight variables is interaction variables created for each governance mechanism and the three performance proxies, respectively. All the control variables introduced in Table 6 are included in each model, but for brevity not reported and available upon request. Table 3 fully defines all the variables used. 
Table 10. The moderating effect of CEO power on the PPS using a two-step multilevel regression

\begin{tabular}{|c|c|c|c|c|c|}
\hline \multirow[b]{3}{*}{$\begin{array}{l}\text { Independent variable } \\
\text { Model (Hierarchical) }\end{array}$} & \multicolumn{5}{|c|}{ Dependent variable } \\
\hline & \multicolumn{2}{|c|}{$\Delta$ All executive directors' pay } & \multicolumn{3}{|c|}{$\triangle \mathrm{CEO}$ pay } \\
\hline & $\begin{array}{l}\triangle \text { TEPAY } \\
(\text { Step } 1)\end{array}$ & $\begin{array}{r}\triangle \mathrm{TEPAY} \\
(\text { Step 2) }\end{array}$ & $\begin{array}{l}\triangle \mathrm{CEPAY} \\
(\text { Step 1) }\end{array}$ & & $\begin{array}{c}\triangle \mathrm{CEPAY} \\
(\text { Step 2) }\end{array}$ \\
\hline \multicolumn{6}{|c|}{ Corporate performance variable: } \\
\hline$\triangle P R E \_T R S_{t}$ & $\begin{array}{l}0.140^{* * * *} \\
(.000)\end{array}$ & $\begin{array}{l}0.165^{* * * *} \\
(.000)\end{array}$ & $\begin{array}{l}0.144^{* * * *} \\
(.000)\end{array}$ & & $\begin{array}{l}0.178^{* * *} \\
(.000)\end{array}$ \\
\hline \multicolumn{6}{|l|}{ CEO power variables: } \\
\hline$\triangle C E O A_{t}$ & $\begin{array}{l}-0.007 \\
(.462)\end{array}$ & $\begin{array}{r}-0.022 \\
(.296)\end{array}$ & $\begin{array}{r}-0.016 \\
(.321)\end{array}$ & & $\begin{array}{r}-0.033 \\
(.285)\end{array}$ \\
\hline$\triangle C E O D_{t}$ & $\begin{array}{l}-0.005 \\
(.584)\end{array}$ & $\begin{array}{r}-0.020 \\
(.528)\end{array}$ & $\begin{array}{r}-0.010 \\
(.552)\end{array}$ & & $\begin{array}{r}-0.025 \\
(.511)\end{array}$ \\
\hline$\triangle C E O O_{t}$ & $\begin{array}{l}0.186^{* * *} \\
(.000)\end{array}$ & $\begin{array}{l}0.263^{* * * *} \\
(.000)\end{array}$ & $\begin{array}{l}0.202^{* * * *} \\
(.000)\end{array}$ & & $\begin{array}{l}0.244^{* * * *} \\
(.000)\end{array}$ \\
\hline$\triangle C E O P_{t}$ & $\begin{array}{l}-0.129^{* * * *} \\
(.000)\end{array}$ & $\begin{array}{l}-0.151^{* * * *} \\
(.000)\end{array}$ & $\begin{array}{l}-0.135^{* * * *} \\
(.000)\end{array}$ & & $\begin{array}{l}-0.158^{* * * *} \\
(.000)\end{array}$ \\
\hline$\triangle C E O R_{t}$ & $\begin{array}{l}0.157^{* * *} \\
(.000)\end{array}$ & $\begin{array}{l}0.183^{* * * *} \\
(.000)\end{array}$ & $\begin{array}{l}0.162^{* * * *} \\
(.000)\end{array}$ & & $\begin{array}{l}0.194^{* * * *} \\
(.000)\end{array}$ \\
\hline$\triangle C E O T_{t}$ & $\begin{array}{l}-0.101^{* *} \\
(.035)\end{array}$ & $\begin{array}{c}-0.120^{* * *} \\
(.030)\end{array}$ & $\begin{array}{l}-0.108^{* *} \\
(.034)\end{array}$ & & $\begin{array}{c}-0.133^{* * *} \\
(.010)\end{array}$ \\
\hline$\triangle F C E O_{t}$ & $\begin{array}{l}0.049^{*} \\
(.086)\end{array}$ & $\begin{array}{l}0.088^{* *} \\
(.036)\end{array}$ & $\begin{array}{l}0.060^{* *} \\
(.047)\end{array}$ & & $\begin{array}{l}0.095^{* *} \\
(.024)\end{array}$ \\
\hline \multicolumn{6}{|l|}{ Interaction variables: } \\
\hline$\Delta P^{*} C E O A_{t}$ & - & $\begin{array}{r}-0.020 \\
(.337)\end{array}$ & - & & $\begin{array}{r}-0.032 \\
(.287)\end{array}$ \\
\hline$\triangle P^{*} C E O D_{t}$ & $\begin{array}{l}- \\
-\end{array}$ & $\begin{array}{r}-0.013 \\
(.568)\end{array}$ & $\begin{array}{l}- \\
-\end{array}$ & & $\begin{array}{r}-0.030 \\
(.498)\end{array}$ \\
\hline$\Delta P^{*} C E O O_{t}$ & - & $\begin{array}{l}0.207^{* * * *} \\
(.000)\end{array}$ & - & & $\begin{array}{l}0.225^{\text {**** }} \\
(.000)\end{array}$ \\
\hline$\triangle P^{*} C E O P_{t}$ & - & $\begin{array}{c}-0.149^{* * *} \\
(.000)\end{array}$ & - & & $\begin{array}{c}-0.157^{* * * *} \\
(.000)\end{array}$ \\
\hline$\Delta P^{*} C E O R_{t}$ & $\begin{array}{l}- \\
-\end{array}$ & $\begin{array}{l}0.165^{* * * *} \\
(.000)\end{array}$ & - & & $\begin{array}{l}0.179^{* * *} \\
(.000)\end{array}$ \\
\hline$\triangle P^{*} C E O T_{t}$ & $\begin{array}{l}- \\
-\end{array}$ & $\begin{array}{c}-0.096^{* *} \\
(.034)\end{array}$ & $\begin{array}{l}- \\
-\end{array}$ & & $\begin{array}{c}-0.118^{* *} \\
(.025)\end{array}$ \\
\hline$\triangle P^{*} F C E O_{t}$ & - & $\begin{array}{l}0.045^{*} \\
(.090)\end{array}$ & - & & $\begin{array}{l}0.080^{* *} \\
(.042)\end{array}$ \\
\hline$\triangle C O N T R O L S$ & Included & Included & Included & & Included \\
\hline Constant & $\begin{array}{l}2.132^{* * * *} \\
(.000)\end{array}$ & $\begin{array}{l}2.502^{* * * *} \\
(.000)\end{array}$ & $\begin{array}{l}2.365^{\text {**** }} \\
(.000)\end{array}$ & & $\begin{array}{l}2.790^{\text {**** }} \\
(.000)\end{array}$ \\
\hline$F$-value & $5.538^{* * *}$ & $6.988^{* * * *}$ & $6.082^{* * * *}$ & & $7.620^{* * * *}$ \\
\hline Adjusted $R^{2}$ & $0.356 \quad \Delta R^{2}: 0.094$ & 0.450 & 0.364 & $\Delta R^{2}: 0.119$ & 0.483 \\
\hline$N$ & 1,521 & 1,521 & 1,521 & & 1,521 \\
\hline $\begin{array}{l}\text { Notes: } P \text {-values are in pare } \\
\text { Errors technique. } * * *, * *, \\
\text { is applied to the variables } \\
(\triangle C E O D) \text {, CEO ownership } \\
(\triangle F C E O) \text {. The next set of } \\
\text { respectively. All the contro } \\
\text { upon request. Table } 3 \text { fully }\end{array}$ & $\begin{array}{l}\text { Sollowing Peterson }(2 \\
\text { lenote significance at th } \\
\text { llows: Predicted total } \\
O O) \text {, CEO power }(\triangle C E \\
\text { variables is interactior } \\
\text { bles introduced in Tabl } \\
\text { all the variables used. }\end{array}$ & $\begin{array}{l}\text { the coefficien } \\
5 \% \text { and } 10 \% 1 \\
n \text { for sharehol } \\
\text { CEO reputatic } \\
\text { iables created } \\
\text { re included in }\end{array}$ & $\begin{array}{l}\text { stimated by us } \\
\text { espectively. } \Delta \\
\left.P R E \_T R S\right), \mathrm{C} \\
\text { ORR), CEO ten } \\
\text { h CEO power } \\
\text { odel, but for t }\end{array}$ & $\begin{array}{l}\text { g the robust } \\
\text { the first-diffe } \\
\mathrm{O} \text { age }(\triangle C E C \\
\text { re }(\triangle C E O T) \text { a } \\
\text { and performan } \\
\text { evity not repo }\end{array}$ & $\begin{array}{l}\text { stered Standard } \\
\text { ce operator and } \\
\text {, CEO duality } \\
\text { founding CEO } \\
(T S R) \text { proxies, } \\
\text { d and available }\end{array}$ \\
\hline
\end{tabular}


Table 11. The moderating effect of CG structure on the PPS using a two-step multilevel regression

\begin{tabular}{|c|c|c|c|c|c|}
\hline \multirow[b]{3}{*}{$\begin{array}{l}\text { Independent variable } \\
\text { Model (Hierarchical) }\end{array}$} & \multicolumn{5}{|c|}{ Dependent variable } \\
\hline & \multicolumn{2}{|c|}{$\Delta$ All executive directors' pay } & \multicolumn{3}{|c|}{$\Delta$ CEO pay } \\
\hline & $\begin{array}{l}\text { TTEPAY } \\
\text { (Step 1) }\end{array}$ & $\begin{array}{c}\triangle \mathrm{TEPAY} \\
\text { (Step 2) } \\
\end{array}$ & $\begin{array}{r}\Delta \text { CEPAY } \\
\text { (Step 1) } \\
\end{array}$ & & $\begin{array}{r}\triangle \mathrm{CEPAY} \\
(\text { Step 2) } \\
\end{array}$ \\
\hline \multicolumn{6}{|c|}{ Corporate performance variable: } \\
\hline$\triangle P R E_{-} T R S_{t}$ & $\begin{array}{l}0.130^{* * * *} \\
(.000)\end{array}$ & $\begin{array}{l}0.149^{* * * *} \\
(.000)\end{array}$ & $\begin{array}{l}0.141^{* * *} \\
(.000)\end{array}$ & & $\begin{array}{l}0.167^{* * * *} \\
(.000)\end{array}$ \\
\hline \multicolumn{6}{|c|}{$\begin{array}{l}\text { Corporate governance structure: } \\
\text { Ownership structure variables: }\end{array}$} \\
\hline$\triangle B O W_{t}$ & $\begin{array}{c}-0.020 \\
(.486)\end{array}$ & $\begin{array}{r}-0.027 \\
(.469)\end{array}$ & $\begin{array}{r}-0.025 \\
(.472)\end{array}$ & & $\begin{array}{r}-0.033 \\
(.454)\end{array}$ \\
\hline$\triangle D O W_{t}$ & $\begin{array}{l}0.132^{* * *} \\
(.000)\end{array}$ & $\begin{array}{l}0.138^{* * * *} \\
(.000)\end{array}$ & $\begin{array}{l}0.143^{* * * *} \\
(.000)\end{array}$ & & $\begin{array}{l}0.156^{* * * *} \\
(.000)\end{array}$ \\
\hline$\Delta I O W_{t}$ & $\begin{array}{l}0.098^{* * *} \\
(.050)\end{array}$ & $\begin{array}{l}0.104^{* *} \\
(.047)\end{array}$ & $\begin{array}{l}0.107^{* *} \\
(.040)\end{array}$ & & $\begin{array}{l}0.110^{* * *} \\
(.029)\end{array}$ \\
\hline \multicolumn{6}{|c|}{ Board structure variables: } \\
\hline$\Delta B S I Z_{t}$ & $\begin{array}{l}-0.260^{* * * *} \\
(.000)\end{array}$ & $\begin{array}{l}-0.275^{* * * *} \\
(.000)\end{array}$ & $\begin{array}{l}-0.278^{* * * *} \\
(.000)\end{array}$ & & $\begin{array}{l}-0.285^{* * *} \\
(.000)\end{array}$ \\
\hline$\triangle F B M_{t}$ & $\begin{array}{l}0.032 \\
(.345)\end{array}$ & $\begin{array}{l}0.036 \\
(.340)\end{array}$ & $\begin{array}{l}0.038 \\
(.337)\end{array}$ & & $\begin{array}{l}0.046 \\
(.323)\end{array}$ \\
\hline$\Delta N C O_{t}$ & $\begin{array}{l}0.138^{* * * *} \\
(.000)\end{array}$ & $\begin{array}{l}0.149^{* * * *} \\
(.000)\end{array}$ & $\begin{array}{l}0.145^{* * * *} \\
(.000)\end{array}$ & & $\begin{array}{l}0.158^{* * * *} \\
(.000)\end{array}$ \\
\hline$\triangle I N E D s_{t}$ & $\begin{array}{l}-0.020 \\
(.554)\end{array}$ & $\begin{array}{l}-0.026 \\
(.540)\end{array}$ & $\begin{array}{l}-0.023 \\
(.545)\end{array}$ & & $\begin{array}{l}-0.036 \\
(.533)\end{array}$ \\
\hline$\Delta R C O_{t}$ & $\begin{array}{l}0.141^{* * *} \\
(.000)\end{array}$ & $\begin{array}{l}0.150^{* * * * *} \\
(.000)\end{array}$ & $\begin{array}{l}0.146^{* * * *} \\
(.000)\end{array}$ & & $\begin{array}{l}0.158^{\text {**** }} \\
(.000)\end{array}$ \\
\hline \multicolumn{6}{|l|}{ Interaction variables: } \\
\hline \multicolumn{6}{|c|}{ Ownership structure variables: } \\
\hline$\Delta P^{*} B O W_{t}$ & $\begin{array}{l}- \\
-\end{array}$ & $\begin{array}{r}-0.013 \\
(.532)\end{array}$ & $\begin{array}{l}- \\
-\end{array}$ & & $\begin{array}{r}-0.025 \\
(.506)\end{array}$ \\
\hline$\Delta P^{*} D O W_{t}$ & $\begin{array}{l}- \\
-\end{array}$ & $\begin{array}{l}0.129^{* * * *} \\
(.000)\end{array}$ & $\begin{array}{l}- \\
-\end{array}$ & & $\begin{array}{l}0.134^{* * * *} \\
(.000)\end{array}$ \\
\hline$\Delta P^{*} I O W_{t}$ & - & $\begin{array}{l}0.090^{*} \\
(.060)\end{array}$ & $\begin{array}{l}- \\
-\end{array}$ & & $\begin{array}{l}0.097^{* * *} \\
(.050)\end{array}$ \\
\hline \multicolumn{6}{|c|}{ Board structure variables: } \\
\hline$\Delta P^{*} B S I Z_{t}$ & $\begin{array}{l}- \\
-\end{array}$ & $\begin{array}{c}-0.252^{* * *} \\
(.000)\end{array}$ & - & & $\begin{array}{l}-0.265^{* * *} \\
(.000)\end{array}$ \\
\hline$\Delta P^{*} F B M_{t}$ & - & $\begin{array}{l}0.025 \\
(.364)\end{array}$ & $\begin{array}{l}- \\
-\end{array}$ & & $\begin{array}{l}0.047 \\
(.330)\end{array}$ \\
\hline$\Delta P^{*} N C O_{t}$ & - & $\begin{array}{l}0.132^{* * * *} \\
(.000)\end{array}$ & $\begin{array}{l}- \\
-\end{array}$ & & $\begin{array}{l}0.146^{* * * *} \\
(.000)\end{array}$ \\
\hline$\Delta P * I N E D s_{t}$ & $\begin{array}{l}- \\
-\end{array}$ & $\begin{array}{l}-0.022 \\
(.584)\end{array}$ & $\begin{array}{l}- \\
-\end{array}$ & & $\begin{array}{l}-0.037 \\
(.569)\end{array}$ \\
\hline$\Delta P^{*} R C O_{t}$ & - & $\begin{array}{c}-0.135^{* * * *} \\
(.000)\end{array}$ & - & & $\begin{array}{l}-0.147^{\text {***** }} \\
(.000)\end{array}$ \\
\hline$\triangle C O N T R O L S$ & Included & Included & Included & & Included \\
\hline Constant & $\begin{array}{l}2.423^{* * * *} \\
(.000)\end{array}$ & $\begin{array}{l}2.652^{* * * *} \\
(.000)\end{array}$ & $\begin{array}{l}2.504^{* * * *} \\
(.000)\end{array}$ & & $\begin{array}{l}2.846^{* * * *} \\
(.000)\end{array}$ \\
\hline$F$-value & $6.576^{* * *}$ & $7.689^{* * * *}$ & $6.865^{* * * *}$ & & $8.531^{\text {**** }}$ \\
\hline Adjusted $R^{2}$ & $0.383 \Delta R^{2}: 0.078$ & 0.461 & 0.398 & $\Delta R^{2}: 0.107$ & 0.490 \\
\hline$N$ & 1,521 & 1,521 & 1,521 & & 1,521 \\
\hline
\end{tabular}


Notes: P-values are in parentheses. Following Peterson (2009), the coefficients are estimated by using the robust Clustered Standard Errors technique. $* * *, * *$, and $*$ denote significance at the $1 \%, 5 \%$ and $10 \%$ levels, respectively. $\Delta$ is the first-difference operator and is applied to the variables as follows: predicted total return for shareholders $\left(\triangle P R E_{-} T R S\right)$, block ownership $(\triangle B O W)$, director ownership $(D O W)$, institutional ownership $(\triangle I O W)$, board size $(\triangle B S I Z)$, number of board meetings $(\triangle F B M)$, the presence of an independent nomination committee $(\triangle N C O)$, percentage of independent non-executive directors $(\triangle I N E D s)$ and the presence of an independent remuneration committee $(\triangle R C O)$. The next set of eight variables is interaction variables created for each governance mechanism and the performance (TRS) proxies, respectively. All the control variables introduced in Table 6 are included in each model, but for brevity not reported and available upon request. Table 3 fully defines all the variables used. 
Table 12. The moderating effect of CEO power on the pay-for-performance relationship with 2SLS

\begin{tabular}{|c|c|c|c|c|c|c|}
\hline \multirow[b]{3}{*}{$\begin{array}{l}\text { Independent variable } \\
\text { Model }\end{array}$} & \multicolumn{6}{|c|}{ Dependent variable } \\
\hline & \multicolumn{3}{|c|}{$\Delta$ All executive directors' pay (2SLS) } & \multicolumn{3}{|c|}{$\triangle \mathrm{CEO}$ pay $(2 \mathrm{SLS})$} \\
\hline & $\begin{array}{l}\triangle \mathrm{TEPAY} \\
\text { (I) }\end{array}$ & $\begin{array}{l}\triangle \mathrm{TEPAY} \\
\text { (II) }\end{array}$ & $\begin{array}{l}\triangle \mathrm{TEPAY} \\
\quad(\mathrm{III})\end{array}$ & $\begin{array}{l}\triangle \mathrm{CEPAY} \\
(\mathrm{IV})\end{array}$ & $\begin{array}{l}\Delta \text { CEPAY } \\
(\mathrm{V})\end{array}$ & $\begin{array}{l}\Delta \mathrm{CEPAY} \\
\quad(\mathrm{VI})\end{array}$ \\
\hline \multicolumn{7}{|c|}{ Corporate performance variable: } \\
\hline$\triangle P R E \_Q_{t}$ & $\begin{array}{l}0.160^{* * * *} \\
(.000)\end{array}$ & $\begin{array}{l}- \\
-\end{array}$ & $\begin{array}{l}- \\
-\end{array}$ & $\begin{array}{l}0.182^{* * * *} \\
(.000)\end{array}$ & $\begin{array}{l}- \\
-\end{array}$ & - \\
\hline$\triangle P R E \_O R O A_{t}$ & - & $\begin{array}{l}0.171^{* * *} \\
(.000)\end{array}$ & $\begin{array}{l}- \\
-\end{array}$ & - & $\begin{array}{l}0.196^{* * * *} \\
(.000)\end{array}$ & - \\
\hline$\Delta P R E_{-} T R S_{t}$ & $\begin{array}{l}- \\
-\end{array}$ & - & $\begin{array}{l}0.165^{* * *} \\
(.000)\end{array}$ & $\begin{array}{l}- \\
-\end{array}$ & - & $\begin{array}{l}0.194^{* * * *} \\
(.000)\end{array}$ \\
\hline \multicolumn{7}{|l|}{ CEO power variables: } \\
\hline$\triangle C E O A_{t}$ & $\begin{array}{l}-0.018 \\
(.318)\end{array}$ & $\begin{array}{r}-0.023 \\
(.305)\end{array}$ & $\begin{array}{r}-0.020 \\
(.311)\end{array}$ & $\begin{array}{r}-0.021 \\
(.308)\end{array}$ & $\begin{array}{r}-0.029 \\
(.295)\end{array}$ & $\begin{array}{r}-0.027 \\
(.298)\end{array}$ \\
\hline$\triangle C E O D_{t}$ & $\begin{array}{l}-0.010 \\
(.560)\end{array}$ & $\begin{array}{l}-0.015 \\
(.542)\end{array}$ & $\begin{array}{r}-0.013 \\
(.550)\end{array}$ & $\begin{array}{r}-0.017 \\
(.538)\end{array}$ & $\begin{array}{r}-0.022 \\
(.527)\end{array}$ & $\begin{array}{r}-0.019 \\
(.530)\end{array}$ \\
\hline$\triangle C E O O_{t}$ & $\begin{array}{l}0.217^{* * * *} \\
(.000)\end{array}$ & $\begin{array}{l}0.226^{* * *} \\
(.000)\end{array}$ & $\begin{array}{l}0.222^{* * * *} \\
(.000)\end{array}$ & $\begin{array}{l}0.228^{* * * *} \\
(.000)\end{array}$ & $\begin{array}{l}0.237^{* * *} \\
(.000)\end{array}$ & $\begin{array}{l}0.231^{\text {***** }} \\
(.000)\end{array}$ \\
\hline$\triangle C E O P_{t}$ & $\begin{array}{l}-0.142^{* * * *} \\
(.000)\end{array}$ & $\begin{array}{l}-0.148^{* * *} \\
(.000)\end{array}$ & $\begin{array}{l}-0.145^{* * * *} \\
(.000)\end{array}$ & $\begin{array}{c}-0.147^{* * * *} \\
(.000)\end{array}$ & $\begin{array}{c}-0.154^{* * * *} \\
(.000)\end{array}$ & $\begin{array}{c}-0.150^{* * * *} \\
(.000)\end{array}$ \\
\hline$\triangle C E O R_{t}$ & $\begin{array}{l}0.174^{* * *} \\
(.000)\end{array}$ & $\begin{array}{l}0.180^{* * * *} \\
(.000)\end{array}$ & $\begin{array}{l}0.177^{* * * *} \\
(.000)\end{array}$ & $\begin{array}{l}0.181^{* * * *} \\
(.000)\end{array}$ & $\begin{array}{l}0.189^{* * * *} \\
(.000)\end{array}$ & $\begin{array}{l}0.187^{* * * *} \\
(.000)\end{array}$ \\
\hline$\triangle C E O T_{t}$ & $\begin{array}{l}-0.109^{* * *} \\
(.029)\end{array}$ & $\begin{array}{l}-0.116^{* * *} \\
(.022)\end{array}$ & $\begin{array}{c}-0.111^{* * *} \\
(.027)\end{array}$ & $\begin{array}{l}-0.117^{\text {*** }} \\
(.024)\end{array}$ & $\begin{array}{l}-0.125^{* * *} \\
(.013)\end{array}$ & $\begin{array}{l}-0.121^{* * *} \\
(.016)\end{array}$ \\
\hline$\triangle F C E O_{t}$ & $\begin{array}{l}0.064^{*} \\
(.051)\end{array}$ & $\begin{array}{l}0.075^{* *} \\
(.040)\end{array}$ & $\begin{array}{l}0.071^{* *} \\
(.044)\end{array}$ & $\begin{array}{l}0.076^{* *} \\
(.038)\end{array}$ & $\begin{array}{l}0.085^{\text {** }} \\
(.030)\end{array}$ & $\begin{array}{l}0.080^{* * *} \\
(.033)\end{array}$ \\
\hline \multicolumn{7}{|l|}{ Interaction variables: } \\
\hline$\triangle P^{*} C E O A_{t}$ & $\begin{array}{r}-0.008 \\
(.359)\end{array}$ & $\begin{array}{r}-0.013 \\
(.340)\end{array}$ & $\begin{array}{r}-0.010 \\
(.347)\end{array}$ & $\begin{array}{r}-0.016 \\
(.332)\end{array}$ & $\begin{array}{r}-0.022 \\
(.328)\end{array}$ & $\begin{array}{r}-0.019 \\
(.330)\end{array}$ \\
\hline$\triangle P^{*} C E O D_{t}$ & $\begin{array}{l}-0.005 \\
(.592)\end{array}$ & $\begin{array}{r}-0.010 \\
(.569)\end{array}$ & $\begin{array}{r}-0.007 \\
(.583)\end{array}$ & $\begin{array}{r}-0.009 \\
(.572)\end{array}$ & $\begin{array}{r}-0.019 \\
(.556)\end{array}$ & $\begin{array}{r}-0.015 \\
(.559)\end{array}$ \\
\hline$\triangle P^{*} C E O O_{t}$ & $\begin{array}{l}0.193^{* * * *} \\
(.000)\end{array}$ & $\begin{array}{l}0.199^{* * * *} \\
(.000)\end{array}$ & $\begin{array}{l}0.195^{\text {***** }} \\
(.000)\end{array}$ & $\begin{array}{l}0.203^{* * * *} \\
(.000)\end{array}$ & $\begin{array}{l}0.220^{* * * *} \\
(.000)\end{array}$ & $\begin{array}{l}0.213^{\text {**** }} \\
(.000)\end{array}$ \\
\hline$\Delta P^{*} C E O P_{t}$ & $\begin{array}{c}-0.127^{* * * *} \\
(.000)\end{array}$ & $\begin{array}{c}-0.135^{\text {**** }} \\
(.000)\end{array}$ & $\begin{array}{c}-0.131^{* * * *} \\
(.000)\end{array}$ & $\begin{array}{c}-0.133^{* * * *} \\
(.000)\end{array}$ & $\begin{array}{c}-0.142^{* * * *} \\
(.000)\end{array}$ & $\begin{array}{c}-0.139^{* * * *} \\
(.000)\end{array}$ \\
\hline$\Delta P^{*} C E O R_{t}$ & $\begin{array}{l}0.155^{\text {**** }} \\
(.000)\end{array}$ & $\begin{array}{l}0.162^{* * * *} \\
(.000)\end{array}$ & $\begin{array}{l}0.159^{* * * *} \\
(.000)\end{array}$ & $\begin{array}{l}0.165^{\text {**** }} \\
(.000)\end{array}$ & $\begin{array}{l}0.174^{* * * *} \\
(.000)\end{array}$ & $\begin{array}{l}0.170^{\text {**** }} \\
(.000)\end{array}$ \\
\hline$\Delta P^{*} C E O T_{t}$ & $\begin{array}{l}-0.085^{\text {** }} \\
(.044)\end{array}$ & $\begin{array}{c}-0.095^{* *} \\
(.037)\end{array}$ & $\begin{array}{c}-0.090^{* *} \\
(.040)\end{array}$ & $\begin{array}{c}-0.097^{* *} \\
(.033)\end{array}$ & $\begin{array}{c}-0.105^{* *} \\
(.026)\end{array}$ & $\begin{array}{c}-0.101^{* *} \\
(.030)\end{array}$ \\
\hline$\Delta P^{*} F C E O_{t}$ & $\begin{array}{l}0.056^{*} \\
(.065)\end{array}$ & $\begin{array}{l}0.064^{*} \\
(.058)\end{array}$ & $\begin{array}{l}0.061^{*} \\
(.060)\end{array}$ & $\begin{array}{l}0.065^{*} \\
(.056)\end{array}$ & $\begin{array}{l}0.070^{* *} \\
(.049)\end{array}$ & $\begin{array}{l}0.068^{*} \\
(.053)\end{array}$ \\
\hline$\triangle C O N T R O L S$ & Included & Included & Included & Included & Included & Included \\
\hline Constant & $\begin{array}{l}2.475^{* * * *} \\
(.000)\end{array}$ & $\begin{array}{l}2.598^{* * * *} \\
(.000)\end{array}$ & $\begin{array}{l}2.485^{* * * *} \\
(.000)\end{array}$ & $\begin{array}{l}2.775^{* * * *} \\
(.000)\end{array}$ & $\begin{array}{l}2.896^{* * * *} \\
(.000)\end{array}$ & $\begin{array}{l}2.782^{* * * *} \\
(.000)\end{array}$ \\
\hline$F$-value & $7.480^{* * * *}$ & $7.594^{* * *}$ & $7.487^{* * *}$ & $7.726^{* * * *}$ & $7.960^{* * * *}$ & $7.843^{* * *}$ \\
\hline Adjusted $R^{2}$ & 0.458 & 0.465 & 0.460 & 0.472 & 0.478 & 0.475 \\
\hline$N$ & 1,521 & 1,521 & 1,521 & 1,521 & 1,521 & 1,521 \\
\hline
\end{tabular}

Notes: P-values are in parentheses. Following Peterson (2009), the coefficients are estimated by using the robust Clustered Standard Errors technique. $* * *, * *$, and $*$ denote significance at the $1 \%, 5 \%$ and $10 \%$ levels, respectively. $\Delta$ is the first-difference operator and is applied to the variables as follows: Predicted Tobin's $Q\left(\triangle P R E_{-} Q\right)$, predicted operating return on assets $\left(\triangle P R E_{-} O R O A\right)$, predicted total return for shareholders $\left(\triangle P R E \_T R S\right)$, CEO age $(\triangle C E O A)$, CEO duality $(\triangle C E O D)$, CEO ownership $(\triangle C E O O)$, CEO power $(\triangle C E O P)$, CEO reputation $(\triangle C E O R)$, CEO tenure $(\triangle C E O T)$ and founding CEO $(\triangle F C E O)$. The next set of seven variables is 
interaction variables created for each CEO power and the three performance proxies, respectively. All the control variables introduced in Table 6 are included in each model, but for brevity not reported and available upon request. Table 3 fully defines all the variables used.

Table 13. The moderating effect of CG structures on the pay-for-performance relationship with 2SLS

\begin{tabular}{|c|c|c|c|c|c|c|}
\hline \multirow[b]{3}{*}{$\begin{array}{l}\text { Independent variable } \\
\text { Model }\end{array}$} & \multicolumn{6}{|c|}{ Dependent variable } \\
\hline & \multicolumn{3}{|c|}{$\Delta$ All executive directors' pay (2SLS) } & \multicolumn{3}{|c|}{$\Delta \mathrm{CEO}$ pay $(2 \mathrm{SLS})$} \\
\hline & $\begin{array}{l}\Delta \text { TEPAY } \\
\text { (I) }\end{array}$ & $\begin{array}{l}\triangle \mathrm{TEPAY} \\
(\mathrm{II})\end{array}$ & $\begin{array}{l}\triangle \mathrm{TEPAY} \\
(\mathrm{III})\end{array}$ & $\begin{array}{l}\Delta \text { CEPAY } \\
\text { (IV) }\end{array}$ & $\begin{array}{l}\triangle \mathrm{CEPAY} \\
(\mathrm{V})\end{array}$ & $\begin{array}{l}\triangle \mathrm{CEPAY} \\
(\mathrm{VI})\end{array}$ \\
\hline \multicolumn{7}{|c|}{ Corporate performance variable: } \\
\hline$\triangle P R E_{-} Q_{t}$ & $\begin{array}{l}0.145^{* * *} \\
(.000)\end{array}$ & - & - & $\begin{array}{l}0.164^{* * * *} \\
(.000)\end{array}$ & - & - \\
\hline$\triangle P R E \_O R O A_{t}$ & - & $\begin{array}{l}0.156^{* * *} \\
(.000)\end{array}$ & - & - & $\begin{array}{l}0.169^{* * * *} \\
(.000)\end{array}$ & - \\
\hline$\triangle P R E_{-} T R S_{t}$ & $\begin{array}{l}- \\
-\end{array}$ & - & $\begin{array}{l}0.153^{* *} \\
(.000)\end{array}$ & $\begin{array}{l}- \\
-\end{array}$ & - & $\begin{array}{l}0.167^{* * * *} \\
(.000)\end{array}$ \\
\hline \multicolumn{7}{|c|}{$\begin{array}{l}\text { Corporate governance structure: } \\
\text { Ownership structure variables: }\end{array}$} \\
\hline$\Delta B O W_{t}$ & $\begin{array}{l}-0.015 \\
(.510)\end{array}$ & $\begin{array}{r}-0.019 \\
(.487)\end{array}$ & $\begin{array}{r}-0.017 \\
(.492)\end{array}$ & $\begin{array}{r}-0.020 \\
(.485)\end{array}$ & $\begin{array}{r}-0.028 \\
(.480)\end{array}$ & $\begin{array}{r}-0.025 \\
(.504)\end{array}$ \\
\hline$\Delta D O W_{t}$ & $\begin{array}{l}0.129^{* * * *} \\
(.000)\end{array}$ & $\begin{array}{l}0.136^{* * *} \\
(.000)\end{array}$ & $\begin{array}{l}0.133^{* * * *} \\
(.000)\end{array}$ & $\begin{array}{l}0.137^{* * * *} \\
(.000)\end{array}$ & $\begin{array}{l}0.144^{* * * *} \\
(.000)\end{array}$ & $\begin{array}{l}0.140^{* * * *} \\
(.000)\end{array}$ \\
\hline$\triangle I O W_{t}$ & $\begin{array}{l}0.082^{*} \\
(.053)\end{array}$ & $\begin{array}{l}0.088^{* *} \\
(.049)\end{array}$ & $\begin{array}{l}0.086^{*} \\
(.051)\end{array}$ & $\begin{array}{l}0.091^{* *} \\
(.046)\end{array}$ & $\begin{array}{l}0.098^{* *} \\
(.037)\end{array}$ & $\begin{array}{l}0.095^{* *} \\
(.040)\end{array}$ \\
\hline \multicolumn{7}{|c|}{ Board structure variables: } \\
\hline$\Delta B S I Z_{t}$ & $\begin{array}{l}-0.255^{* * *} \\
(.000)\end{array}$ & $\begin{array}{l}-0.267^{* * * *} \\
(.000)\end{array}$ & $\begin{array}{l}-0.262^{* * * *} \\
(.000)\end{array}$ & $\begin{array}{c}-0.271^{* * * *} \\
(.000)\end{array}$ & $\begin{array}{l}-0.278^{* * * *} \\
(.000)\end{array}$ & $\begin{array}{c}-0.274^{* * * *} \\
(.000)\end{array}$ \\
\hline$\Delta F B M_{t}$ & $\begin{array}{l}0.027 \\
(.362)\end{array}$ & $\begin{array}{l}0.036 \\
(.350)\end{array}$ & $\begin{array}{l}0.030 \\
(.359)\end{array}$ & $\begin{array}{l}0.034 \\
(.352)\end{array}$ & $\begin{array}{l}0.039 \\
(.341)\end{array}$ & $\begin{array}{l}0.037 \\
(.344)\end{array}$ \\
\hline$\Delta N C O_{t}$ & $\begin{array}{l}0.129^{* * *} \\
(.000)\end{array}$ & $\begin{array}{l}0.137^{* * * *} \\
(.000)\end{array}$ & $\begin{array}{l}0.135^{* * * *} \\
(.000)\end{array}$ & $\begin{array}{l}0.138^{* * *} \\
(.000)\end{array}$ & $\begin{array}{l}0.148^{* * * *} \\
(.000)\end{array}$ & $\begin{array}{l}0.146^{* * * *} \\
(.000)\end{array}$ \\
\hline$\triangle I N E D s_{t}$ & $\begin{array}{l}-0.016 \\
(.575)\end{array}$ & $\begin{array}{l}-0.021 \\
(.564)\end{array}$ & $\begin{array}{l}-0.018 \\
(.569)\end{array}$ & $\begin{array}{l}-0.024 \\
(.557)\end{array}$ & $\begin{array}{l}-0.029 \\
(.548)\end{array}$ & $\begin{array}{l}-0.026 \\
(.550)\end{array}$ \\
\hline$\Delta R C O_{t}$ & $\begin{array}{l}0.135^{* * *} \\
(.000)\end{array}$ & $\begin{array}{l}0.145^{* * *} \\
(.000)\end{array}$ & $\begin{array}{l}0.141^{* * * *} \\
(.000)\end{array}$ & $\begin{array}{l}0.144^{* * *} \\
(.000)\end{array}$ & $\begin{array}{l}0.149^{* * * *} \\
(.000)\end{array}$ & $\begin{array}{l}0.147^{* * * *} \\
(.000)\end{array}$ \\
\hline \multicolumn{7}{|l|}{$\begin{array}{l}\text { Interaction variables: } \\
\text { Ownership structure }\end{array}$} \\
\hline$\Delta P^{*} B O W_{t}$ & $\begin{array}{r}-0.005 \\
(.546)\end{array}$ & $\begin{array}{r}-0.009 \\
(.537)\end{array}$ & $\begin{array}{r}-0.007 \\
(.541)\end{array}$ & $\begin{array}{r}-0.011 \\
(.534)\end{array}$ & $\begin{array}{r}-0.018 \\
(.523)\end{array}$ & $\begin{array}{r}-0.016 \\
(.529)\end{array}$ \\
\hline$\Delta P^{*} D O W_{t}$ & $\begin{array}{l}0.116^{* * * *} \\
(.000)\end{array}$ & $\begin{array}{l}0.125^{* * * *} \\
(.000)\end{array}$ & $\begin{array}{l}0.122^{* * * *} \\
(.000)\end{array}$ & $\begin{array}{l}0.126^{* * * *} \\
(.000)\end{array}$ & $\begin{array}{l}0.132^{* * * *} \\
(.000)\end{array}$ & $\begin{array}{l}0.129^{* * * *} \\
(.000)\end{array}$ \\
\hline$\Delta P^{*} I O W_{t}$ & $\begin{array}{l}0.073^{*} \\
(.072)\end{array}$ & $\begin{array}{l}0.086^{*} \\
(.065)\end{array}$ & $\begin{array}{l}0.081^{*} \\
(.068)\end{array}$ & $\begin{array}{l}0.087^{*} \\
(.063)\end{array}$ & $\begin{array}{l}0.094^{*} \\
(.057)\end{array}$ & $\begin{array}{l}0.090^{*} \\
(.060)\end{array}$ \\
\hline Board structure vari & bles: & & & & & \\
\hline$\Delta P^{*} B S I Z_{t}$ & $\begin{array}{c}-0.235^{\text {**** }} \\
(.000)\end{array}$ & $\begin{array}{l}-0.247^{* * * *} \\
(.000)\end{array}$ & $\begin{array}{l}-0.241^{\text {***** }} \\
(.000)\end{array}$ & $\begin{array}{c}-0.249^{* * * *} \\
(.000)\end{array}$ & $\begin{array}{c}-0.258^{* * * *} \\
(.000)\end{array}$ & $\begin{array}{c}-0.252^{* * * *} \\
(.000)\end{array}$ \\
\hline$\Delta P^{*} F B M_{t}$ & $\begin{array}{l}0.013 \\
(.395)\end{array}$ & $\begin{array}{l}0.019 \\
(.383)\end{array}$ & $\begin{array}{l}0.016 \\
(.389)\end{array}$ & $\begin{array}{l}0.020 \\
(.381)\end{array}$ & $\begin{array}{l}0.028 \\
(.369)\end{array}$ & $\begin{array}{l}0.024 \\
(.373)\end{array}$ \\
\hline$\Delta P^{*} N C O_{t}$ & $\begin{array}{l}0.118^{* * * *} \\
(.000)\end{array}$ & $\begin{array}{l}0.127^{* * * *} \\
(.000)\end{array}$ & $\begin{array}{l}0.124^{* * * *} \\
(.000)\end{array}$ & $\begin{array}{l}0.128^{* * * *} \\
(.000)\end{array}$ & $\begin{array}{l}0.137^{* * * *} \\
(.000)\end{array}$ & $\begin{array}{l}0.133^{* * * *} \\
(.000)\end{array}$ \\
\hline$\Delta P * I N E D s_{t}$ & $\begin{array}{l}-0.009 \\
(.610)\end{array}$ & $\begin{array}{l}-0.015 \\
(.598)\end{array}$ & $\begin{array}{l}-0.011 \\
(.605)\end{array}$ & $\begin{array}{l}-0.017 \\
(.592)\end{array}$ & $\begin{array}{l}-0.025 \\
(.587)\end{array}$ & $\begin{array}{l}-0.021 \\
(.590)\end{array}$ \\
\hline$\Delta P^{*} R C O_{t}$ & $\begin{array}{l}0.126^{* * * *} \\
(.000)\end{array}$ & $\begin{array}{l}-0.132^{* * * *} \\
(.000)\end{array}$ & $\begin{array}{c}-0.129^{* * * *} \\
(.000)\end{array}$ & $\begin{array}{c}-0.133^{* * * *} \\
(.000)\end{array}$ & $\begin{array}{c}-0.138^{* * * *} \\
(.000)\end{array}$ & $\begin{array}{c}-0.136^{* * * *} \\
(.000)\end{array}$ \\
\hline$\triangle C O N T R O L S$ & Included & Included & Included & Included & Included & Included \\
\hline
\end{tabular}




\begin{tabular}{lllllll} 
Constant & $2.780^{* * *}$ & $2.798^{* * *}$ & $2.791^{* * *}$ & $2.972^{* * *}$ & $2.995^{* * * *}$ & $2.983^{* * *}$ \\
& $(.000)$ & $(.000)$ & $(.000)$ & $(.000)$ & $(.000)$ & $(.000)$ \\
$F$-value & $8.783^{* * * *}$ & $8.797^{* * * *}$ & $8.792^{* * *}$ & $8.978^{* * *}$ & $8.993^{* * * *}$ & $8.987^{* * *}$ \\
Adjusted $R^{2}$ & 0.482 & 0.488 & 0.485 & 0.492 & 0.497 & 0.494 \\
$N$ & 1,521 & 1,521 & 1,521 & 1,521 & 1,521 & 1,521 \\
\hline
\end{tabular}

Notes: P-values are in parentheses. Following Peterson (2009), the coefficients are estimated by using the robust Clustered Standard Errors technique. $* * *, * *$, and $*$ denote significance at the $1 \%, 5 \%$ and $10 \%$ levels, respectively. $\Delta$ is the first-difference operator and is applied to the variables as follows: predicted Tobin's $\mathrm{Q}\left(\triangle P R E_{-} Q\right)$, predicted operating return on assets $\left(\triangle P R E \_O R O A\right)$, predicted total return for shareholders $\left(\triangle P R E \_T R S\right)$, block ownership $(\triangle B O W)$, director ownership $(D O W)$, institutional ownership $(\triangle I O W)$, board size $(\triangle B S I Z)$, number of board meetings $(\triangle F B M)$, the presence of an independent nomination committee $(\triangle N C O)$, percentage of independent non-executive directors $(\triangle I N E D s)$ and the presence of an independent remuneration committee $(\triangle R C O)$. The next set of eight variables is interaction variables created for each governance mechanism and the three performance proxies, respectively. All the control variables introduced in Table 6 are included in each model, but for brevity not reported and available upon request. Table 3 fully defines all the variables used. 